\title{
Firm Life Cycle and Real-Activity Based Earnings Management
}

\author{
Neerav Nagar \\ Suresh Radhakrishnan
}

W.P. No. 2015-12-01

December 2015

The main objective of the working paper series of the IIMA is to help faculty members, research staff and doctoral students to speedily share their research findings with professional colleagues and test their research findings at the pre-publication stage. IIMA is committed to maintain academic freedom. The opinion(s), view(s) and conclusion(s) expressed in the working paper are those of the authors and not that of IIMA.

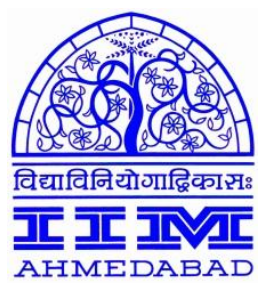

INDIAN INSTITUTE OF MANAGEMENT

AHMEDABAD-380 015

INDIA 


\title{
Firm Life Cycle and Real-Activity Based Earnings Management
}

\author{
Neerav Nagar \\ Indian Institute of Management Ahmedabad, India \\ Email: neeravn@iimahd.ernet.in
}

\author{
Suresh Radhakrishnan* \\ Jindal School of Management, University of Texas at Dallas, Richardson, Texas, U.S.A. \\ Email: sradhakr@utdallas.edu
}

\begin{abstract}
We examine real-activity based earnings management, i.e., cuts in discretionary innovation/marketing spending and overproduction for meeting the earnings benchmark of avoiding losses across firms' life cycle. We use the cash flow components to classify a firm's life cycle. We hypothesize and find that firms in the growth and mature stages exhibit real-activity based earnings management to meet earnings target of avoiding losses; but firms in the introductory stage do not. We also hypothesize and find that such real-activity based earnings management to meet the earnings benchmark of avoiding losses is associated with future performance for mature firms, but not so for growth firms. Collectively, our evidence shows the importance of considering firm's life cycle when examining real-activity based earnings management.
\end{abstract}

Keywords: Real earnings management; Firm life cycle; Firm performance.

*Corresponding author. 


\section{Introduction}

Graham et al. (2005) in their survey of financial executives report that roughly $80 \%$ of executives would "consider taking actions that will deliver earnings, as long as the actions are within GAAP and the real sacrifices are not too large." Consistent with this, Roychowdhury (2006) develops measures for various real-activity based earnings management and documents that firms avoid reporting losses through real-activity based earnings management. Gunny (2010) documents that firms that avoid reporting losses through real-activity earnings management are positively associated with the future operating performance, which suggests that real-activity based earnings management is not opportunistic. However, Cohen and Zarowin (2010) show that for firms with seasoned equity offerings, real-activity based earnings management is negatively associated with future operating performance; indicating that real-activity based earnings management is likely to be opportunistic. Our objective is to provide insights into whether realactivity based earnings management is opportunistic by examining real-activity based earnings management separately for the firm's life cycle.

A firm's life cycle consists of the following stages: introduction, growth, maturity and decline (see Dickinson, 2011; Drake, 2015). Spence (1977, 1979, 1981) provides insights into the activities of firms in each stage. ${ }^{1}$ Based on the activities that firms focus on in each stage, i.e., the supply-side, we argue that firms in the introduction stage are not likely to engage in realactivities based earnings management to avoid reporting losses because they are not likely to have much discretion over their spending so as to engage in discretionary cuts to their innovation

\footnotetext{
${ }^{1}$ Gort and Klepper (1982) characterize these stages for the industry's life cycle and Jovanovic (1982) develops arguments about the firms' activities in the industry's life cycle. The decline stage includes firms in the shake-out stage as well as the decline stage. We combine the shake-out and decline stages because our focus is on the introductory, growth and mature stage firms.
} 
and marketing spending. On the demand-side as well, the providers of capital are likely to expect firms in the introduction stage to report losses, i.e., the burn rate, which likely dampens the incentive to engage in real-activities based earnings management to achieve earnings benchmarks. However, firms in the growth and mature stages are likely to have the ability and the incentive to engage in real-activities based earnings management to achieve earnings benchmarks. We thus hypothesize that firms in the introduction stage are not likely to engage in real-activities based earnings management to avoid reporting losses; and firms in the growth and mature stages are likely to engage in real-activity based earnings management to achieve earnings benchmark. We also hypothesize that if firms in the growth and mature stages are efficient (opportunistic) in cutting discretionary expenses then these firms that engage in realactivity based earnings management to avoid reporting losses will be positively (negatively) associated with future operating performance.

Our sample consists of firms in the Compustat database from 1987 to 2014. Following Roychowdhury (2006) and Gunny (2010) we measure the following components of real-activity based earnings management: (a) reduction in research and development expenses, (b) reduction in selling, general and administrative expenses, and (c) reduction in cost of goods sold through over production. Similar to Gunny (2010) we combine the three components into one composite measure of real-activity based earnings management. Following Dickinson (2011) we use cash flow components to classify firm-years into their life cycle stages. In particular, firms with negative cash flow from operating and investing activities and positive cash flow from financing activities are classified as introductory stage firms; firms with positive cash flow from operating and financing activities and negative cash flow from investing activities are classified as growth 
stage firms; firms with negative cash flow from investing and financing activities and positive cash flows from operating activities are classified as the mature firms; and, all other firms are classified as decline stage firms.

We find that for firms in the growth and mature stages real-activity based earnings management is positively associated with just meeting the earnings benchmark of avoiding losses; and for firms in the introductory stage real-activity based earnings management is not associated with just meeting the earnings benchmark of avoiding losses. These results support the hypothesis that firms in the growth and mature stages are the ones with both the discretion and incentives to engage in real-activity based earnings management to attain earnings benchmarks.

We find that firms in the growth and mature stages that engage in real-activity based earnings management to just meet the earnings benchmark of avoiding losses exhibit better industry-adjusted return on assets in the subsequent year compared to the growth and mature stage firms that do not engage in such real-activity based earnings management; albeit weakly so for growth firms. To examine the weak result with respect to the firms in the growth stage, we examine the future performance using one-year ahead industry-adjusted cash flow from operations and cumulative three years' industry-adjusted return on assets. We find that for both growth and mature stage firms real-activity based earnings management to just meet the earnings benchmark of avoiding losses is positively associated with next year's cash flow from operations. However, when we consider the cumulative three-year ahead industry-adjusted return on assets to account for the long-term performance consequences of the discretionary spending cuts, we find that for firms in the mature stage real-activity based earnings management to just 
meet the earnings benchmark of avoiding losses is positively associated with better future performance, but it is not so for growth firms. This indicates that real-activity based earnings management is structural for mature firms, and thus efficient; while for growth firms the realactivity based earnings management may not be so. ${ }^{2}$

Even though growth firms are more likely to raise capital, and thus have stronger incentives to meet earnings targets, we explore the incentive effect more directly by examining the firms' merger and acquisition activity and equity capital raising activity. We classify firms that have had a merger or raised capital in the year as the ones with incentives to engage in realactivity based earnings management. Here again we find that while firms in both the growth and mature stages exhibit real-activity based earnings management, compared to firms without incentives the result is stronger for firms with incentives. In addition, among the firms with stronger incentives to meet earnings benchmarks, real-activity based earnings management to meet earnings benchmark is positively associated with one-year ahead industry-adjusted return on assets for both firms in growth and mature firms; and similar to earlier results weakly so for growth firms. Among the firms with less stronger incentives to meet earnings benchmarks, realactivity based earnings management to meet earnings benchmark is positively associated with one-year ahead industry-adjusted return on assets only for the mature firms.

Collectively, these findings suggest that both Gunny's (2010) and Cohen and Zarowin's (2010) results can be reconciled as follows. Real-activity based earnings management to meet earnings benchmarks is, on average, not opportunistic for firms in the mature stage consistent with Gunny's (2010) finding. However, real-activity based earnings management to meet

\footnotetext{
${ }^{2}$ By structural, we imply that firms in the mature stage likely use the opportunity to meet earnings benchmarks to disinvest from negative net present value projects.
} 
earnings benchmarks is, on average, opportunistic for firms in the growth stage consistent with Cohen and Zarowin's (2010) finding. This is likely to be the case because firms in the growth stage are likely to have more capital market pressure and thus, stronger incentives to meet earnings benchmarks.

Even though conceptually real-activity based earnings management is likely to be related to the firm's life cycle, the cash flow components that we use to classify the firm's life cycle could be cause for concern for two reasons. First, the cash flow from operations is a performance measure that is also potentially managed by the firm. Lee (2012) documents evidence consistent with the notion that firms manage cash flow from operations upwards, by shifting between cash flow components and/or changing the timing of the payment/receipt. As such, a firm that is in the introductory stage could be misclassified as being in the growth or mature stage. Such misclassifications of the life cycle would render cash flow components as a proxy for the life cycle stage to be noisy, and bias against finding support for our hypotheses. Second, the cutting of discretionary spending for marketing and innovation activities is likely to directly increase the cash flow from operations. This mechanical relationship could in turn shift the firm's life cycle classification to growth and/or mature firms - firms with positive cash flow from operations. To address these concerns we drop firms with small positive cash flow from operations and find similar results.

In other robustness tests, first we consider the performance matched real-activity based earnings management measure as proposed by Cohen et al. (2015) noting that such adjustment for performance is likely to make the relationship of real-activity based earnings management more tenuous. We find that firms in any of the stages do not engage in real-activity based 
earnings management to just meet the earnings benchmark of avoiding losses. This is likely because the life-cycle stages themselves are related to performance, and hence performance matching is likely to bias against finding support for the hypothesis. Second, we consider an alternative classification of firm life cycle stages based on Anthony and Ramesh (1992). Using the Anthony and Ramesh's (1992) classification we find that firms in all stages exhibit realactivity based earnings management. We also find that the real-activity based earnings management to meet earnings benchmark of avoiding losses is positively associated with future performance for firms in the introduction and growth stages.

We contribute to the literature on real-activity based earnings management in a variety of ways. First, we show the importance of considering the firm's life cycle, because firms in the introductory stage are not likely to have the discretion to engage in real-activity based earnings management. This provides additional validation for Roychowdhury's (2006) measure. The life cycle stage is an ex ante measure of the incentives for capital requirements as well as the ability to cut discretionary spending and/or overproduce, and as such provides a way to match on ex ante performance. ${ }^{3}$

Second, we extend Cohen and Zarowin's (2010) finding by showing that firms in the growth stage that engage in real-activity based earnings management to just meet the earnings benchmark of avoiding losses do not exhibit better industry-adjusted return on assets in the longrun, indicating that real-activity based earnings management in these firms is on average opportunistic. Our life cycle stage is an ex ante measure of the potential for the firm to require

\footnotetext{
${ }^{3}$ Even though the firms' life cycle stages are an ex ante concept, it is measured using cash flow components. Firms classified as being in the growth stage are the ones who have raised capital either through debt or equity. Accordingly, under this measurement view, the life cycle stages (especially those firms classified as in the growth stage) provide a more comprehensive measure of the incentives to meet earnings target of avoiding losses.
} 
capital as well as have earnings as an important benchmark. In this sense, our results are not likely to be driven by selection issues, and show the importance of considering the incentives as Cohen and Zarowin (2010) rightly postulate. Third, we extend Gunny's (2010) finding by showing that firms in the mature stage and not firms in the introductory and growth stages that engage in real-activity based earnings management to just meet the earnings benchmark of avoiding losses exhibit better industry-adjusted return on assets in the next year. Lastly, our results are consistent with the notion expressed in the survey of Graham et al. (2005) that managers would consider real-activity based earnings management only if the sacrifice, i.e., the cost is not too much; the sacrifice for the introductory stage firms are likely to be very high. As such, real-activity decisions are likely to be more structural and not opportunistic.

The rest of paper is organized as follows: Section 2 provides the background literature and the empirical expectations. Section 3 contains the research design and variable definitions. Section 4 contains the empirical analysis, and Section 5 provides some concluding remarks.

\section{Background Literature, Empirical Expectations and Research Design}

\subsection{Background Literature}

This paper builds upon two streams of literature: real-activity based earning management literature and the firm life cycle literature. Accordingly, we provide the background literature pertaining to both these streams below.

\subsubsection{Real-activity based Earnings Management}

Prior research documents that managers cut discretionary spending to attain earnings targets. The accounting rules require that innovation, marketing and human resource 
development related spending be treated as period costs and charged off in the period they are incurred. These outlays on innovation, marketing and human resource development are likely to provide a benefit in the long-run and not the short-run. In effect, the consequences in terms of future benefits of cutting spending on these items is not likely to be known for some years to come. As a result, firms can opportunistically cut spending/outlays on innovation, marketing and human resource development to attain earnings reporting targets - the real-activity based earnings management.

Baber et al. (1991) find that firms' research and development spending is smaller for firms who avoid losses or negative growth. Dechow and Sloan (1991) show that firms spend less on research and development in the final years of chief executive officers' tenure. Bens et al. (2002) document that firms whose earnings per share is diluted because of stock option exercise cut research and development and capital spending to attain earnings benchmarks. Darrough and Rangan (2005) find evidence consistent with firms cutting their research and development spending before an initial public offering to attain a higher offer price. Collectively, this evidence is consistent with Graham et al. (2005) who find in their survey of financial executives the following: "We find strong evidence that managers take real economic actions to maintain accounting appearances. In particular, $80 \%$ of survey participants report that they would decrease discretionary spending on $\mathrm{R} \& \mathrm{D}$, advertising and maintenance to meet an earnings target. More than half $(55.3 \%)$ state that they would delay starting a new project to meet an earnings target, even if such delay entailed a small sacrifice in value."

Consistent with the above findings, Roychowdhury (2006) defines real-activity based earnings management as "actions that deviate from normal business practices, undertaken with 
the primary objective to mislead certain stakeholders into believing that earnings benchmarks have been met in the normal course of operations." Accordingly, he develops the following measures of real-activities that deviate from normal operations: (a) increasing sales through early recognition or providing lenient credit terms, (b) reducing cost of goods sold by overproducing, and (c) cutting research and development and selling, general and administrative spending. He validates the measures by showing that firms that cut spending compared to the benchmark normal spending are positively associated with firms just avoiding reporting losses. Siriviriyakul (2014) provides some evidence casting doubts on the validity of the large sample real-activity based earnings management measure developed by Roychowdhury (2006). Accordingly, our objective is to examine whether real-activity based earnings management is different for different life cycle stages, and thereby provide additional validation for the large sample measure.

Cohen and Zarowin (2010) show that the operating performance after a seasoned equity offering is worse for firms that engage in real-activity based earnings management than for firms that did not engage in such earnings management. This suggests that real-activity based earnings management is opportunistic and has some real economic consequences in terms of poor performance in later years. Bushee (1998) and Roychowdhury (2006) provide indirect evidence on real-activity based earnings management being opportunistic by showing that institutional investors, especially those with a long-term outlook, decrease their ownership in firms that engage in such activity.

Gunny (2010) examines the real-activity based earnings management and future performance by developing arguments based on evidence that firms that achieve earnings 
benchmarks exhibit better future performance. She documents that firms that avoid reporting losses through real-activity earnings management are positively associated with the future operating performance, which suggests that real-activity based earnings management is not opportunistic. As such, while prior research shows that cutting spending on innovation, marketing and human resource development are positively associated with attaining earning benchmarks, the evidence on whether these actions lead to better or worse future performance is mixed. Accordingly, the objective of this study is to examine the incidence of real-activity based earnings management and its relationship with future performance for different stages of the firm's life cycle.

\subsubsection{Firm's Life Cycle}

Dickinson (2011) posits that firm's life cycle comprises of distinct stages that are determined by internal factors, such as strategy choice, financial resources and managerial ability, and external factors, such as competition and state of the economy. She develops a measure of the firm's life cycle stages using the cash flow from operating, investing and financing activities and shows that the earnings persistence is related to the firm's life cycle stages. She also shows that the efficiency and profit margin measures are related differently to future profitability in different life cycle stages.

Drake (2015) uses the firm's life cycle stage proxy developed by Dickinson (2011) and provides a rationale for why book-tax differences are associated with persistence of earnings (see Hanlon, 2005) and future earnings growth (Lev and Nissim, 2004). Drake (2015) posits that firms engage in fundamentally different transactions in different life cycle stages, and this turn results in different book-tax differences over the life cycle. As such, she predicts and finds that 
the prior results on book-tax differences, earnings persistence and growth are driven by the firm's life cycle. In a similar vein, we posit that the fundamental differences across the firm's life cycle stages provides differential ability/incentives for firms to engage in real-activity based management; and accordingly validate Roychowdhury's (2006) large sample measure of realactivity based earnings management as well as examine whether this is opportunistic.

\subsection{Development of Empirical Expectations}

\subsubsection{Real-activity Based Earnings Management to Avoid Losses}

Firms in the introductory or start-up stage are likely to make heavy investments in innovation and marketing activities, compared to their market share or sales, so as to create market acceptance (Bain, 1956; Caves, 1972; Scherer, 1970). These investments are considered as expenses and form part of the operating cash flow. Firms in the growth stage attain a certain degree of foothold in the market and continue to make heavy investments in innovation, market branding as well as equipment so as to grow their market share (Bain, 1956; Caves, 1972; Scherer, 1970). Firms in the mature stage direct their attention to improve efficiency, and generate profits/returns to providers of capital (Selling and Stickney, 1989). Firms in the decline stage are likely in that situation because of technological disruptions (Christensen, 2003), and thus engage in disinvestments and restructuring activities (Kimberly, 1980; Miller and Friesen, 1984; Quinn and Cameron, 1983).

Firms in the introductory stage are not likely to use real-activity based earnings management for two reasons. First, on the demand-side investors are not likely to focus on shortterm earnings as much as the investments in innovation and market branding activities. As such, 
managers are not likely to have the pressure of reporting profits. ${ }^{4}$ It follows that for firms in the introductory stage the earnings benchmark of avoiding losses may not be relevant. Second, on the supply-side firms in an introductory stage are not likely to cut spending on innovation or marketing activities or overproduce to meet earnings targets because the discretionary portion of such expenditures may be minimal, if not non-existent for these capital strapped firms (see Knott and Posen, 2005). Consistent with this notion, studies document that firms in the introductory stage or entrepreneurial firms, operate with investments at a minimum level (for example see Castanias and Helfat, 2001). Overall, the innovation and marketing expenditures for firms in the introductory stage are necessary and form the building blocks for the future prospects of the company. As such, these firms are not likely to have discretion to cut these spending.

Firms in the growth stage are likely to use real-activity earnings management to meet earnings benchmarks, because they are likely to need external/internal financing to expand operations (Jovanovic, 1982). Furthermore, the founders of companies are likely to exit, i.e., cash out during the growth stage (Amit et al., 1998; Granlund and Taipaleenmaki, 2005). In a similar vein, firms in the mature stage are likely to face capital market pressure to meet earnings targets (Burgstahler and Dichev, 1997). ${ }^{5}$ These demand-side factors are likely to provide incentives for managers to engage in real-activity based earnings management for both growth and mature firms. On the supply-side, firms in growth and mature stages are likely to have the discretion to disinvest from unproductive innovations and marketing activities because they are likely to have a portfolio of projects - of which some are not so promising (Hamilton and Chow, 1993; Hitt et

\footnotetext{
${ }^{4}$ Graham et al. (2005) surveyed the large companies that are more likely to be in the mature stage.

5 Even though Burstahler and Dichev (1997) do not explicitly consider the life cycle stages, the examples and arguments are premised on steady state, i.e., mature companies.
} 
al., 1996; Hoskisson and Hitt, 1994); or delay investments in new innovation and marketing projects (Hitt et al., 1996). The combination of the discretion as well as the incentive to meet earnings benchmarks is likely to make firms in growth and mature stages engage in real-activity based earnings management. These arguments lead us to the following hypothesis.

\section{Hypothesis $\mathrm{H1}$}

H1a: Firms in the growth and mature stages that just meet the earnings benchmark of avoiding losses exhibit real-activity based earnings management.

H1b: Firms in the introductory stage that just meet the earnings benchmark of avoiding losses do not exhibit real-activity based earnings management.

Collectively, Hypotheses H1a and H1b posit that Roychowdhury's (2006) results are driven by firms in the growth and mature stages. If Roychowdhury's (2006) measure does not capture the real-activity based earnings management to meet earnings benchmarks as argued by Siriviriyakul (2014), then firms in all the three stages - introductory, growth and mature - will exhibit real-activity based earnings management to just meet the earnings benchmark of avoiding losses.

It is important to note that we have not hypothesized real-activity based earnings management for firms in the decline stage. Firms in the decline stage are not likely to have the discretion to manage real-activities to manage reported earnings. These firms faced with threats from new disruptive technologies reposition themselves by disinvesting and restructuring (see Christensen, 2003). As such, firms in the decline stage are not likely to have the discretion to cut 
spending on innovation and marketing activities (for example, see Sudarsanam and Lai, 2001). ${ }^{6}$ In effect, it will not be possible to disentangle disinvestments from real-activity based earnings management; and accordingly we do not hypothesize real-activity based earnings management for firms in the decline stage; however, we provide the empirical results for decline firms for purpose of reference.

\subsubsection{Future Performance and Real-activity Based Earnings Management to Avoid Losses}

Following Gunny (2010) given the existence of real-activity based earnings management for the growth and mature stages, we examine whether these cuts in discretionary spending are opportunistic by examining subsequent performance. On the one hand, if these cuts are opportunistic then we expect firms that just meet earnings benchmark of avoiding losses through cuts in spending to be negatively associated with future performance (see for example Matsunaga and Park, 2001). On the other hand, if these cuts are not opportunistic then we expect firms that just meet earnings benchmark of avoiding losses through cuts in spending to be positively associated with future performance. Bartov et al. (2002) show that firms that just meet earnings benchmarks are associated with future operating performance and suggest that meeting benchmarks increases the credibility of the firm and avoids litigation. Furthermore, meeting such benchmarks provides a signal of managerial competence. Consistent with the latter arguments, Gunny (2010) finds that firms that just meet earnings benchmark of avoiding losses through cuts in spending are positively associated with future performance.

\footnotetext{
${ }^{6}$ The repositioning of the US automobile manufacturers in light of the Japanese automobile manufacturer's quality and production practices in the late 1980s and early 1990s provides a good example. General Motors entered into a joint venture with Toyota to manufacture automobiles to learn the lean manufacturing practices - the Nummi plant, and closed many of the then existing plants (see Gomes-Casseres, 2009). General Motors engaged in both heavy investments as well as disinvestments during this period, which would have been classified as a decline stage in our classification.
} 
Firms in the growth stage are likely to have more incentives to meet the earnings target of avoiding losses because of their need to raise capital to support growth. While this argument is similar to the Cohen and Zarowin's (2010) argument of incentives to engage in real-activity based earnings management, the life cycle stage is an ex ante measure of the potential for requiring capital. In this sense, the results are not likely to be driven by selection issues. Collectively, these arguments lead us to propose the following hypothesis.

\section{Hypothesis 2}

H2a: Firms in the mature stage that just meet the earnings benchmark of avoiding losses through real-activity based earnings management are positively associated with future performance.

$\boldsymbol{H} 2 \boldsymbol{b}$ : Firms in the growth stage that just meet the earnings benchmark of avoiding losses through real-activity based earnings management are not positively associated with future performance.

Hypothesis 2a essentially posits that Gunny's (2010) results are driven by mature stage firms.

\section{Research Design and Variable Definitions}

\subsection{Variable Definitions}

\subsubsection{Measuring Firm's Life Cycle}

Following Dickinson (2011) we use cash flow components to classify the firm's life cycle stages. Firms with negative cash flows from operating and investing activities and positive cash flows from financing activities are classified as introductory stage firms, Intro. Firms with positive cash flow from operating and financing activities and negative cash flow from investing 
activities are classified as growth stage firms, Growth. Firms with negative cash flow from investing and financing activities and positive cash flows from operating activities are classified as the mature firms, Mature. All other firms are classified as decline stage firms, Decline. ${ }^{7}$

Lee (2012) documents evidence consistent with the notion that firms manage cash flow from operations upwards, by shifting between cash flow components and/or changing the timing of the payment/receipt. As such, a firm that is likely to be in the introductory stage could be misclassified as being in the growth or mature stage. Such misclassifications of the life cycle would render cash flow components as a proxy for the life cycle stage to be noisy, and bias against finding support for our hypotheses.

\subsubsection{Earnings Bins}

We consider four earnings bins based on the net income scaled by total assets: (a) firms that missed the benchmark, (b) firms that just missed the benchmark, (b) firms that just beat the benchmark, and (d) firms that beat the benchmark. Specifically, we classify firm-years with net income between zero and one percent of total assets as firms that just meet the earnings benchmark of avoiding losses, i.e., if $\mathrm{NI}_{t} / \mathrm{ASSET}_{\mathrm{t}}$ is between zero and 0.01, J_BEAT=1, otherwise J_BEAT=0. We classify firm-years with net income between zero and negative one percent of total assets as firms that just missed the earnings benchmark of avoiding losses, i.e., if $\mathrm{NI}_{\mathrm{t}} / \mathrm{ASSET}_{\mathrm{t}}$ is between zero and -0.01, J_MISS=1, otherwise J_MISS=0. We classify firm-years with net income greater than or equal to one percent of total assets as firms that beat the earnings

\footnotetext{
7 Dickinson (2011) separates our decline stage classification into shake-out and decline stages. In unreported analysis we separate our decline stages into the two categories and find similar results. We choose to combine these stages because both these stages will be engaged in disinvestments, and as such for our test it is appropriate to combine these stages.
} 
benchmark of avoiding losses, i.e., if $\mathrm{NI}_{t} / \mathrm{ASSET}_{\mathrm{t}}$ is greater than or equal to 0.01 , BEAT=1, otherwise BEAT=0. We classify firm-years with net income less than negative one percent of total assets as firms that missed the earnings benchmark of avoiding losses, i.e., if $\mathrm{NI}_{\mathrm{t}} / \mathrm{ASSET}_{\mathrm{t}}$ is less than 0.01 , MISS $=1$, otherwise MISS $=0$.

\subsubsection{Real-activity based Earnings Management}

Following Gunny (2010) we measure real-activity based earnings management, RM as the sum of the following components: (a) an abnormal decrease in spending on research and development, RD; (b) an abnormal decrease in spending on selling, general and administrative expenses, SGA; and (c) an abnormal decrease in cost of goods sold through overproduction. The abnormal RD, SGA and PROD are computed by subtracting the normal levels by estimating the following models as in Gunny (2010).

$$
\begin{aligned}
& \mathrm{RD}_{\mathrm{t}}=\alpha+\beta_{1}\left[1 / \mathrm{ASSET}_{\mathrm{t}-1}\right]+\beta_{2} \log \left(\mathrm{MKT}_{-} \mathrm{VAL}_{\mathrm{t}}\right)+\beta_{3} \text { TOBIN's_Q }_{\mathrm{t}}+\beta_{4} \mathrm{INT}_{\mathrm{t}} \\
& +\beta_{5} \mathrm{RD}_{\mathrm{t}-1}+\text { error } \\
& \text { SGA }_{t}=\alpha+\beta_{1}\left[1 / \mathrm{ASSET}_{\mathrm{t}-1}\right]+\beta_{2} \log \left(\mathrm{MKT}_{-} \mathrm{VAL}_{\mathrm{t}}\right)+\beta_{3} \text { TOBIN's_Q }_{\mathrm{t}}+\beta_{4} \mathrm{INT}_{\mathrm{t}} \\
& +\beta_{5} \text { CH_SALE }+\beta_{6} \text { NEG } \times \text { CH_SALE } t+\text { error } \\
& \text { PROD }_{\mathrm{t}}=\alpha+\beta_{1}\left[1 / \mathrm{ASSET}_{\mathrm{t}-1}\right]+\beta_{2} \log \left(\mathrm{MKT}_{-} \mathrm{VAL}_{\mathrm{t}}\right)+\beta_{3} \text { TOBIN's_Q }_{\mathrm{t}} \\
& +\beta_{4} \mathrm{SALE}_{\mathrm{t}}+\beta_{5} \mathrm{CH} \_\mathrm{SALE}_{\mathrm{t}}+\beta_{6} \mathrm{CH} \mathrm{SALE}_{\mathrm{t}-1}+\text { error }
\end{aligned}
$$

where $\mathrm{RD}$ is the research and development expense, SGA is the selling, general and administrative expense, PROD is the production expense computed as the cost of goods sold plus the change in inventory, ASSET is the total assets, MKT_VAL is the market capitalization computed as common shares outstanding multiplied by the fiscal-year end stock price; TOBIN's_Q is the sum of market value of equity, preferred stock, long-term debt and debt in current liabilities divided by the total assets; INT is internal funds computed as the sum of income before extraordinary items, depreciation and research and development expenses; SALE 
is the net sales; CH_SALE is the change in net sales and NEG is an indicator variable that equals one when CH_SALE is negative, and zero otherwise. All variables other than Log(MKT_VAL) and TOBIN's_Q are scaled by the beginning total assets. Equations (1a), (1b) and (1c) are estimated for each 2 digit industry with at least 15 non-missing RD, SGA and PROD observations. AB_RD, AB_SGA and AB_PROD are the abnormal RD, SGA and PROD, respectively and are computed as the actual RD, SGA and PROD minus the predicted RD, SGA and PROD obtained from equations (1a), (1b) and (1c), respectively. Our measure for realactivity based earnings management is $\mathrm{AB} \_\mathrm{RM}=\mathrm{AB} \_\mathrm{RD}+\mathrm{AB} \_\mathrm{SGA}-\mathrm{AB} \_$PROD. ${ }^{8}$

All variable definitions are provided in Appendix A, and the results of estimating equation (1) are provided in the Appendix B.

\subsection{Research Design}

To test Hypothesis H1, we modify Roychowdhury’s (2006) and Gunny’s (2010) model as in equation (2).

$$
\begin{aligned}
& \mathrm{AB} \_\mathrm{RM}_{\mathrm{t}}=\alpha+\beta_{1} \mathrm{~J}_{-} \mathrm{BEAT}_{\mathrm{t}}+\beta_{2} \mathrm{~J}_{-} \mathrm{MISS}_{\mathrm{t}}+\beta_{3} \mathrm{MISS}_{\mathrm{t}}+\beta_{4} \log \left(\mathrm{ASSET}_{\mathrm{t}}\right)+\beta_{5} \mathrm{MTB}_{\mathrm{t}} \\
& +\beta_{6} \mathrm{ROA}_{\mathrm{t}}+\text { Industry F.E. }+ \text { Year F. E. + error , }
\end{aligned}
$$

where J_BEAT is one if net income over total assets is between zero and 0.01, and zero otherwise; J_MISS is one if net income over total assets is between zero and -0.01 , and zero otherwise; MISS is one if net income over total assets is less than -0.01; ASSET is the total assets; MTB is the market value of equity over book value of equity where market value of

\footnotetext{
${ }^{8}$ Gunny (2010) considers the gains from asset sales as well. In unreported analysis we include the gains from asset sales in total AB_RM and find similar results. We do not include this in the reported results because this component is relatively small in magnitude and infrequent, as suggested by the spearman correlation of AB_RM with and without gains from asset sales of 0.994 .
} 
equity is computed as common shares outstanding multiplied by the fiscal-year end stock price; ROA is the return on assets computed as income before extraordinary items over previous year's total assets. We estimate equation (2) for firms in each life cycle stage separately. In all of our estimations we delete observations with absolute value of student residuals greater than 3.50 to mitigate the effect of outliers on our inferences and correct the standard errors for computing tstatistics using firm and year clusters (Petersen, 2009). We also estimate equation (2) for all stages put together so as to compare our results with that of prior studies.

Equation (2) includes the earnings bins of J_MISS and MISS because Siriviriyakul (2014) provides evidence that real-activity based earnings management is prevalent in the other earnings bins as well. Furthermore, if we do not consider the other earnings bins, then the benchmark for the coefficient estimate $\beta_{1}$ are the earnings bins, BEAT, J_MISS and MISS put together. In effect, the coefficients $\beta_{1}, \beta_{2}$ and $\beta_{3}$ captures the average additional real-activity based earnings management by J_BEAT, J_MISS and MISS firms compared to BEAT firms. BEAT firms provide an appropriate benchmark to assess the real-activity based earnings management because firms that beat the earnings target are likely to have no incentive to engage in real-activity based earnings management in order to meet earnings targets. J_MISS and MISS firms could have the incentives to engage in real-activity based earnings management for incentives similar to that of taking a big bath. Of course, we estimate equation (2) without J_MISS and MISS so as to compare our results with those in Roychowdhury (2006) and Gunny (2010).

To test Hypothesis H2, we modify Gunny’s (2010) model as in equation (3).

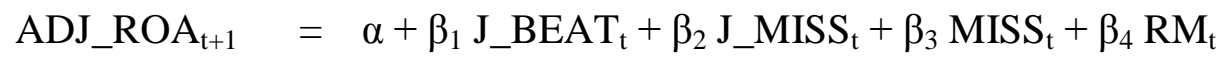




$$
\begin{aligned}
& +\beta_{5} \mathrm{RM}_{\mathrm{t}} \times \mathrm{J} \_\mathrm{BEAT} \mathrm{t}_{\mathrm{t}}+\beta_{6} \mathrm{RM}_{\mathrm{t}} \times \mathrm{J} \_\mathrm{MISS}_{\mathrm{t}}+\beta_{7} \mathrm{RM}_{\mathrm{t}} \times \mathrm{MISS}_{\mathrm{t}} \\
& +\beta_{8} \text { ADJ_ROA }{ }_{\mathrm{t}}+\beta_{9} \log \left(\mathrm{ASSET}_{\mathrm{t}}\right)+\beta_{10} \mathrm{MTB}_{\mathrm{t}}+\beta_{11} \mathrm{RETURN}_{\mathrm{t}}+ \\
& \beta_{12} \mathrm{ZSCORE}_{\mathrm{t}}+\text { Industry F.E. + Year F.E. + error , }
\end{aligned}
$$

where ADJ_ROA is the industry-adjusted return on assets computed as the firm's return on assets minus the two-digit industry-year average return on assets; RM is one if AB_RM is in the lowest quintile, and zero otherwise; RETURN is the size-adjusted abnormal stock returns computed as the difference in buy and hold returns for the firm and size matched decile portfolio; ZSCORE is a measure of financial health computed using a variant of Altman's (1968) Z-Score.

We estimate equation (3) for firms in each life cycle stage separately. As with equation (2) in all of our estimations we delete observations with absolute value of student residuals greater than 3.50 to mitigate the effect of outliers on our inferences and correct the standard errors for computing t-statistics using firm and year clusters (Petersen, 2009). We also estimate equation (3) for all stages put together so as to compare our results with those of prior studies.

The test variable is $\mathrm{RM} \times \mathrm{J} \_\mathrm{BEAT}$ and based on hypothesis $\mathrm{H} 2 \mathrm{a}$ and $\mathrm{H} 2 \mathrm{~b}$ we expect that the coefficient estimate, $\beta_{5}$ for Mature firms to be positive, and that for Intro, Growth and Decline firms to be non-positive. Equation (3) includes the interactions of RM with earnings bins of J_MISS and MISS also because of the reasons mentioned earlier. If we do not consider these interactions, then the benchmark for the coefficient estimate $\beta_{5}$ may be biased. We also estimate equation (3) without these interactions so as to compare our results with those in Gunny (2010). 


\section{Empirical Analysis}

\subsection{Sample}

The sample comprises of firms in the Compustat and CRSP database from 1987 to 2014 with data available for all variables. Our sample starts from 1987 because data on cash flows required to classify the firms' life cycle stages is available from that year onwards. Following Gunny (2010) we delete firms in the financial services (SIC 6000-7000) and regulated industries (SIC 4400-5000), because the real-activity based earnings management measures are not likely to apply to them. We winsorize all continuous variables at $1 \%$ and $99 \%$ of their respective empirical distributions. The final sample size consists of 60,151 firm-year observations, with $11,774(20 \%)$ being in the Intro stage, $16,268(27 \%)$ in the Growth stage, $21,585(36 \%)$ in the Mature stage, and 10,524 (17\%) in the Decline stage.

\subsection{Real-activity Earnings Management to Just Avoid Loss}

Table 1, Panel A provides the mean and median of the variables used in equation (2) for the whole sample under the column titled "All stages" and each of the four life cycle stages separately. The mean (median) AB_RM for Intro, Growth, Mature and Decline are 0.056, 0.113, 0.072 and $0.003(-0.037,0.032,0.023$ and -0.048$)$, respectively. This indicates that the abnormal real-earnings management is different across the life cycle stages: it is lowest for firms in the Growth stage, followed by firms in the Mature and Introductory stages with the highest for firms in the Decline stage. The AB_RM is right skewed for firms in all stages. Simply put, this shows that the measure of real earnings management, especially for the firms in the introductory and decline stages may, on average, be capturing disinvestments from negative net present value 
projects. The mean (median) of Log(ASSET) for Intro, Growth, Mature and Decline are 3.294, 5.559, 5.895 and $4.215(3.259,5.442,5.838$ and 4.016), respectively. This suggests that firms in the Growth and Mature stages are larger in size than firms in the Intro and Decline stages, which is in line with the premise that firms in the Growth and Mature stages are likely to have the ability to cut spending on innovation and marketing activities. The mean (median) of market to book ratio, MTB for Intro, Growth, Mature and Decline are 4.962, 3.372, 2.872 and 3.185 $(2.308,2.283,1.932$ and 1.613), respectively. This suggests that from an incentive perspective, firms in the Intro stage followed by firms in the Growth and Mature stages are likely to have greater incentives to maintain their stock prices and hence meet the earnings benchmark of avoiding losses. The mean (median) of return on assets, ROA for Intro, Growth, Mature and Decline are $-0.611,0.052,0.058$ and $-0.204(-0.240,0.059,0.059$ and -0.072$)$, respectively. This suggests that firms in the Growth and Mature stages are more profitable, while firms in the Intro and Decline stages are not; as such, the incentives for meeting earnings targets may be less important for firms in the Intro and Decline stages than for firms in the Growth and Mature stages. $^{9}$

Table 1, Panel B provides the results of estimating equation (2) in the left side columns. The coefficient estimate on J_BEAT for the Intro, Growth, Mature and Decline stages are 0.016, $-0.063,-0.042$ and -0.055 (t-statistics $=0.776,-4.830,-2.963$ and -3.147 ), respectively. Consistent with Hypothesis H1a, firms that belong to the Growth and Mature stages engage in real-activity based earnings management to meet the earnings benchmark of avoiding losses.

\footnotetext{
${ }^{9}$ The difference of the mean and median of the individual stages when compared with the Mature stage is statistically significant in all cases except the difference in medians of ROA for the Growth stage and the Mature stage.
} 
Also, consistent with Hypothesis $\mathrm{H} 1 \mathrm{~b}$ firms in the Intro stage do not exhibit the propensity to engage in real-activity based earnings management to just meet the earnings benchmark of avoiding losses. The results suggest that firms in the Decline stage also exhibit the propensity to engage in real-activity based earnings management to just meet the earnings benchmark of avoiding losses; however, this may be attributable to disinvestments. Overall, the results support Hypothesis H1a and H1b, when BEAT is used as the benchmark.

Even though it is not the focus of our hypothesis, it is interesting to examine the coefficient on J_MISS. The coefficient estimates on J_MISS for the Intro, Growth, Mature and Decline stages are $-0.067,-0.077,-0.034$ and -0.092 (t-statistics $=-2.346,-4.708,-1.835$ and 6.725), respectively. This indicates that firms in all life cycle stages that just miss the earnings benchmark also engage in real-activity based earnings management. This is consistent with the findings of Siriviriyakul (2014) who finds that cutting spending is prevalent in the other earnings bins as well. However, we follow Roychowdhury's (2006) premise that firms that just avoid losses, i.e., suspect firms exhibit abnormal cuts in expenses/spending.

The right side columns provide the results of estimating equation (2) without J_MISS and MISS as in Roychowdhury (2006) and Gunny (2010). The results support Hypothesis H1a and H1b. Furthermore, as noted earlier the coefficient estimate on J_BEAT is biased upwards for all stages because the propensity to engage in real-activity based earnings management is not randomly distributed across the other three earnings bins (see Siriviriyakul, 2014). 


\subsection{Future Performance and Real-activity Earnings Management to Just Avoid Loss}

Table 2, Panel A provides the mean and median of the additional variables used in equation (3) for the whole sample under the column titled "All stages" and each of the four stages separately. The mean industry-adjusted return on assets, ADJ_ROA is the highest for the firms in the mature stage, followed by firms in the growth stage; firms in the Intro and Decline stages exhibit lower than industry average earnings performance. The mean (median) of sizeadjusted buy and hold returns, RETURN for Intro, Growth, Mature and Decline are 1.726, 1.197, 0.335 and $0.245(-0.116,-0.026,-0.075$ and -0.182$)$, respectively. This shows that RETURN is right skewed for all firms, with a few firms exhibiting very large size-adjusted returns; the right skewness is very large for firms in the Intro and Growth stage possibly because of the presence of a few "winners." As such, we winsorize as well eliminate outliers using the standardized residuals as discussed in the research design section.

Table 2, Panel B provides the results of estimating equation (3) in the left side columns. the coefficient estimate on RM $\times$ J_BEAT for the Intro, Growth, Mature and Decline stages are $0.004,0.017,0.025$ and -0.032 (t-statistics $=-0.181,1.867,2.981$ and -1.486 ), respectively. Consistent with Hypothesis H2a, firms in the Mature stage that just meet the earnings benchmark of avoiding losses through real-activity based earnings management are positively associated with future performance, while not so consistent with Hypothesis H2b, firms in the Growth stage that just meet the earnings benchmark of avoiding losses through real-activity based earnings management are also positively associated with future performance, but weakly so. The results 
affirm Gunny's (2010) results for firms in the Mature stage as well as for firms in the Growth stage, albeit weakly for Growth firms.

We provide the results for firms in the Intro and Decline stages even though Hypotheses $2 \mathrm{a}$ and $2 \mathrm{~b}$ do not pertain to these stages. Firms in the Intro and Decline stages that just meet the earnings benchmark of avoiding losses through real-activity based earnings management are not associated with future performance - this is consistent with the notion that the AB_RM for firms in these stages may not capture real-activity based earnings management.

The right side columns provide the results of estimating equation (3) without J_MISS and MISS as in Gunny (2010). The results support Hypothesis H2a and H2b, the coefficient on $\mathrm{RM} \times \mathrm{J} \_\mathrm{BEAT}$ for the Mature stage is positive and significant, while that for Growth stage is statistically insignificant at the conventional levels.

Collectively, the evidence suggests that firms in the Growth and Mature stages exhibit real-activity based earnings management; however, for firms in the Mature stage the discretionary cuts are on average efficient.

\subsection{Additional Analysis}

First, following Gunny (2010) we examine future cash flow from operations as an alternative measure of future performance, because the results support Hypothesis $2 \mathrm{~b}$ weakly. However, it is important to note that since cash flow from operations forms a basis for the classification of life cycle stages, the results of this analysis should be interpreted with caution. The mean (median) of cash flow from operations, CFO for Intro, Growth, Mature and Decline are $-0.409,0.128,0.134$ and $-0.113(-0.164,0.101,0.118$ and -0.033$)$, respectively; these statistics shows that firms in Growth and Mature stages are more likely to have positive cash 
flows, by design. Table 3, Panel A provides the results of estimating equation (3) using cash flow from operations instead of return on assets as the dependent variable. For sake of brevity, we do not report the coefficients on the control variables. Consistent with the results discussed in Table 2, Panel B, firms in the Growth and Mature stages that just meet the earnings benchmark of avoiding losses through real-activity based earnings management are positively associated with future cash flow from operations. Specifically, the coefficient estimate on RM $\times$ J_BEAT for the Intro, Growth, Mature and Decline stages are $-0.010,0.026,0.018$ and -0.004 (t-statistics $=-$ $0.520,3.913,2.158$ and -0.305$)$, respectively. The right side columns provide the results of estimating equation (3) without J_MISS and MISS as in Gunny (2010). The results support Hypothesis $2 \mathrm{a}$ but not $2 \mathrm{~b}$.

Second, we estimate equation (3) using the cumulative industry-adjusted return on assets for next three years instead of the one-year ahead industry-adjusted return on assets. We do this because the measure of discretionary spending cuts embedded in AB_RM relate primarily to innovation and marketing activities, and such activities are likely to have a long-term consequence rather than a short-term consequence (Ravenscraft and Scherer, 1982). Table 3, Panel B provides the results of estimating equation (3) in the left side columns. The coefficient estimate on RM $\times$ J_BEAT for the Intro, Growth, Mature and Decline stages are 0.007, 0.017, 0.065 and -0.106 (t-statistics $=0.102,0.655,3.531$ and -1.622$)$, respectively. This result supports Hypotheses $2 \mathrm{a}$ and $2 \mathrm{~b}$. Specifically, real-activity based earnings management in order to meet earnings benchmark of avoiding losses for firms in the Mature stage is efficient, while for firms in the Growth stage it is not related to long term future performance. 
Third, we examine the incentive arguments made in the development of the hypotheses more directly. For this purpose, we classify firms that have raised equity capital or engaged in mergers and acquisition activity as firms with an incentive to meet the earnings benchmark of avoiding losses: such firms have INCENTIVE=1, and all other firms have INCENTIVE=0. Table 4, Panel A provides the results of estimating equation (2) for INCENTIVE=1 and INCENTIVE=0 groups. We find that firms in the Growth and Mature stages in both INCENTIVE=1 and INCENTIVE=0 groups exhibit real-activity based earnings management to meet the earnings benchmark of avoiding losses; with the propensity of doing so being higher in the INCENTIVE=1 group than the INCENTIVE=0 group. In addition, firms in the Intro stage do not exhibit such propensity consistent with Hypothesis 1b. This is consistent with the arguments embedded in the development of the hypothesis. Both from a demand and supply side firms in the Intro stage do not have an incentive to meet earnings benchmarks; this is so even though the cash flow from financing for these firms is positive. Furthermore, the firms with INCENTIVE $=0$ in the Decline stage exhibit real-activity based earnings management to meet the earnings benchmark of avoiding losses, indicating that controlling for the life cycle stage is important when examining real-activity based earnings management.

Table 4, Panel B provides the results of estimating equation (3) for INCENTIVE=1 and INCENTIVE=0 groups. Similar to the results discussed along with Table 2, Panel B we find support for Hypothesis 2a, and weak support for Hypothesis $2 \mathrm{~b}$.

Table 5 provides the results of estimating equations (2) and (3) for each of the components of AB_RM i.e. AB_RD, AB_SGA and AB_PROD. For the sake of brevity, we report the coefficients and t-statistics only on the variables J_BEAT and RM $\times$ J_BEAT. Our 
results discussed in Tables 1 and 2 are attributable to firms' decisions to cut discretionary spending on marketing and overproduction; and not to cuts in innovation spending.

\subsection{Robustness Tests}

Even though conceptually real-activity based earnings management is likely to be related to the firm's life cycle, the cash flow components that we use to classify the firm's life cycle could be directly related to real-activity based earnings management. In other words, one possible concern in our research design is that the cutting of discretionary spending for marketing and innovation activities is likely to directly increase the cash flow from operations. Furthermore, Lee (2012) shows the propensity of firms to manage cash flow from operations. These factors could in turn shift Intro or Decline stage firms to growth and/or mature firms firms with positive cash flow from operations. To address this we drop firms with small positive cash flows from operations. Specifically, we delete firm-year observations where the cash flows from operations is between zero and one percent of total assets and estimate equations (2) and (3). ${ }^{10}$ The results are reported in Table 6 . In equation (2), the coefficient estimate on J_BEAT for the Intro, Growth, Mature and Decline stages are 0.016, $-0.056,-0.042$ and -0.059 (t-statistics $=$ $0.773,-4.132,-2.924$ and -3.167$)$, respectively; and in equation (3) the coefficient estimate on RM $\times$ J_BEAT for the Intro, Growth, Mature and Decline stages are $-0.004,0.020,0.022$ and 0.031 (t-statistics $=-0.203,1.943,2.702$ and -1.519), respectively. Overall, the results are similar to those reported in Tables 1 and 2.

We then use the firm-specific AB_RM and match the firm based on ROA to the closest firm in the industry-year, and compute the performance matched abnormal real-activity based

\footnotetext{
${ }^{10}$ We use one percent as the cut-off so as to be consistent with the earnings benchmark.
} 
earnings management measure as the difference between the $A B \_R M$ and the matched firm AB_RM (see Cohen et al., 2015). In equation (2), the coefficient estimate on J_BEAT for the Intro, Growth, Mature and Decline stages are 0.105, 0.025, -0.012 and 0.027 (t-statistics $=3.433$, 1.044, -0.708 and 0.956 ), respectively. In general, we do not find real-activity based earnings management for meeting the earnings benchmark of avoiding losses for firms in any of the life cycle stages. In equation (3), the coefficient estimate on RM $\times$ J_BEAT for the Intro, Growth, Mature and Decline stages are 0.022, $-0.006,0.024$ and 0.006 (t-statistics $=0.992,-0.561,3.961$ and 0.260), respectively. Consistent with Hypotheses 2a and 2b, we do find that only Mature firms who engage in real-activity based earnings management exhibit better superior future performance, while the firms in the other stages do not. However, the inference should be made with caution, because the estimation of equation (2) suggests no real-activity based earnings management. This non-result for Hypothesis $\mathrm{H} 1$ is not surprising when one notes that in separately estimating equation (2) for the life cycle stages, we match on performance - firms in each of the life cycle stages have different benchmarks that are important.

We use the Anthony and Ramesh (1992) approach to classify the firm's life cycle stages. Specifically, each year, firms are ranked into three groups based on each of these variables: (a) dividend payout ratio, (b) sales growth, (c) capital expenditure, and (d) firm age. Firms in the lowest (highest) terciles of dividend payout ratio and firm age are ranked as one (three), and firms in the highest (lowest) terciles of sales growth and capital expenditure are ranked as one (three). We then calculate a score (sum of ranks) for each firm, ranging from four to twelve. Firms with scores of 4 and 5 are classified as Intro; 6 and 7 as Growth; 8 to 10 as Mature; and the rest as Decline. In equation (2), the coefficient estimate on J_BEAT for the Intro, Growth, 
Mature and Decline stages are $-0.204,-0.068,-0.074$ and -0.084 (t-statistics $=-3.515,-3.282$, 8.808 and -3.014), respectively. We find that firms in all life cycle stages exhibit real-activity based earnings management to meet the earnings benchmark of avoiding losses. In equation (3), the coefficient estimate on RM×J_BEAT for the Intro, Growth, Mature and Decline stages are 0.126, 0.036, 0.006 and 0.000 (t-statistics $=2.299,2.092,0.842$ and 0.016), respectively. This suggests that the real-activity based earnings management to meet earnings benchmark of avoiding losses is positively associated with future performance for Intro and Growth firms. This finding is consistent with Dickinson's (2011) conclusion that the cash flow based classification of life cycle stages is more appropriate.

We estimate seemingly unrelated regressions to estimate equations (2) and (3) so as to account for the correlations among the residuals of the individual regressions. In equation (2), the coefficient estimate on J_BEAT for the Intro, Growth, Mature and Decline stages are 0.016, $0.063,-0.042$ and -0.055 (z-statistics $=0.560,-4.690,-3.760$ and -2.600 ), respectively. In equation (3), the coefficient estimate on $\mathrm{RM} \times \mathrm{J} \_$BEAT for the Intro, Growth, Mature and Decline stages are $-0.004,0.017,0.025$ and -0.032 (z-statistics $=-0.080,1.430,2.660$ and -0.870 ), respectively. These results are consistent with those discussed in Tables 1 and 2.

\section{Concluding Remarks}

We examine whether firms use real-activity based earnings management, i.e., cuts in discretionary spending in innovation and marketing activities, and overproduction in order to meet the earnings benchmark of avoiding losses across different life cycle stages; and whether such real-activity based earnings management to meet the earnings benchmark of avoiding losses is associated with future performance differently across the life cycle stages. We hypothesize that 
firms in the introductory and decline stages are not likely to have the capacity to cut spending in a discretionary manner, and the investors also are not likely to expect such firms to meet earnings benchmarks. As such, we expect real-activity based earnings management for firms in the growth and mature stages. We find support for this hypothesis. Furthermore, we hypothesize that firms in the mature stage are likely to be using the discretionary spending cuts, efficiently such that these actions are positively related to future performance; for firms in the growth phase this may not be the case. We find support for real-activity based earnings management of firms in the mature stage being positively associated with future performance; and weakly so for growth firms. We thus find support for the measures of real-activity based earnings management, as well as the support for such earnings management being opportunistic especially for growth firms. Future research should consider controlling for the firm life cycle stages before drawing conclusions about real-activity based earnings management. 


\section{References}

Altman, E. I., 1968. Financial ratios, discriminant analysis and the prediction of corporate bankruptcy. The Journal of Finance 23(4), 589-609.

Amit, R., Brander, J., Zott, C., 1998. Why do venture capital firms exist? Theory and Canadian evidence. Journal of Business Venturing 13, 441-466.

Anthony, J. H., Ramesh, K., 1992. Association between accounting performance measures and stock prices: A test of the life cycle hypothesis. Journal of Accounting and Economics 15, 203-227.

Baber, W. R., Fairfield, P. M., Haggard, J. A., 1991. The effect of concern about reported income on discretionary spending decisions: The case of research and development. The Accounting Review 66(4), 818-829.

Bain, J. S., 1956. Barriers to New Competition. Harvard University Press, Cambridge, MA.

Bartov, E., Givoly, D., Hayn, C., 2002. The rewards to meeting or beating earnings expectations. Journal of Accounting and Economics 332, 173-204.

Bens, D. A., Nagar, V., Wong, M. H. F., 2002. Real investment implications of employee stock option exercises. Journal of Accounting Research 40(2), 359-393.

Burstahler D., Dichev, I., 1997. Earnings management to avoid earnings decreases and losses. Journal of Accounting and Economics 24, 99-126.

Bushee, B. J., 1998. The influence of institutional investors on myopic R\&D investment behavior. The Accounting Review 73(3), 305-333.

Castanias, R. P., Helfat, C. E., 2001. The managerial rents model: Theory and empirical analysis. Journal of Management 27, 661-678.

Caves, R. E., 1972. American Industry: Structure, Conduct, and Performance. 3rd edn., PrenticeHall: Englewood Cliffs, NJ.

Christensen, C., 2003. The Innovator's Dilemma: The Revolutionary Book that Will Change the Way You Do Business. Harper Collins, New York, NY.

Cohen D., Pandit, S., Wasley, C., Zach, T., 2015. Measuring real activity management. Working Paper, University of Texas at Dallas. 
Cohen, D., Zarowin, P., 2010. Accrual-based and real earnings management activities around seasoned equity offerings. Journal of Accounting and Economics 50, 2-19.

Darrough, M., Rangan, S., 2005. Do insiders manipulate earnings when they sell their shares in an initial public offering? Journal of Accounting Research 43(1), 1-33.

Dechow, P. M., Sloan, R. G., 1991. Executive incentives and the horizon problem: An empirical investigation. Journal of Accounting and Economics 14, 51-89.

Dickinson, V., 2011. Cash flow patterns as a proxy for firm life cycle. The Accounting Review 86(6), 1969-1994.

Drake, K. D., 2015. Does firm life cycle inform the relation between book-tax differences and earnings persistence? Working Paper, University of Arizona.

Gomes-Casseres, B., 2009. Nummi: What Toyota Learned and GM Didn't. Harvard Business Publishing. Retrieved from https://hbr.org/2009/09/nummi-what-toyota-learned on November 19, 2015.

Gort, M., Klepper, S., 1982. Time paths in the diffusion of product innovations. The Economic Journal 92(367), 630-653.

Graham, J. R., Harvey, C. R., Rajgopal, S., 2005. The economic implications of corporate financial reporting. Journal of Accounting and Economics 40, 3-73.

Granlund, M., Taipaleenmäki, J., 2005. Management control and controllership in new economy firms - a life cycle perspective. Management Accounting Research 16, 21-57.

Gunny, K. A., 2010. The relation between earnings management using real activities manipulation and future performance: Evidence from meeting earnings benchmarks. Contemporary Accounting Research 27(3), 855-888.

Hamilton, R. T., Chow, Y. K., 1993. Why managers divest - evidence from New Zealand's largest companies. Strategic Management Journal 14, 479-484.

Hanlon, M., 2005. The persistence and pricing of earnings, accruals, and cash flows when firms have large book-tax differences. The Accounting Review 80(1), 137-166.

Hitt, M. A., Hoskisson, R. E., Johnson, R. A., Moesel, D. D., 1996. The market for corporate control and firm innovation. The Academy of Management Journal 39(5), 1084-1119.

Hoskisson, R. E., Hitt, M. A., 1994. Downscoping: How to Tame the Diversified Firm. Oxford University Press, New York. 
Jovanovic, B., 1982. Selection and the evolution of industry. Econometrica 50(3), 649-670.

Kimberly, J. R., 1980. Initiation, Innovation, and Institutionalization in the Creation Process. In J.R. Kimberly and R. H. Miles, eds., The Organizational Life Cycle: Issues in the Creation, Transformation, and Decline of Organizations. Jossey-Bass, San Francisco, CA.

Knott, A. M., Posen, H. E., 2005. Is failure good? Strategic Management Journal 26, 617-641.

Lee, L. F., 2012. Incentives to inflate reported cash from operations using classification and timing. The Accounting Review 87(1), 1-33.

Lev, B, Nissim, D., 2004. Taxable income, future earnings, and equity values. The Accounting Review 79(4), 1039-1074.

Matsunaga, S. R., Park, C. W., 2001. The effect of missing a quarterly earnings benchmark on the CEO's annual bonus. The Accounting Review 76(3), 313-332.

Miller, D., Friesen, P. H., 1984. A longitudinal study of the corporate life cycle. Management Science 30(10), 1161-1183.

Petersen, M. A., 2009. Estimating standard errors in finance panel data sets: Comparing approaches. The Review of Financial Studies 22(1), 435-480.

Quinn, J. B., Cameron, K., 1983. Organizational life cycles and shifting criteria of effectiveness: Some preliminary evidence. Management Science 29, 33-51.

Ravenscraft, D., Scherer, F. M., 1982. The lag structure of returns to research and development. Applied Economics 14, 603-620.

Roychowdhury, S., 2006. Earnings management through real activities manipulation. Journal of Accounting and Economics 42(3), 335-370.

Scherer, F. M., 1970. Industrial Market Structure and Economic Performance. Rand McNally, Chicago, IL.

Selling, T., Stickney, S., 1989. The effects of business environment and strategy on a firm's rate of return on assets. Financial Analysts Journal 45(1), 43-52.

Siriviriyakul, S., 2014. Re-examining real earnings management to avoid losses. Working Paper, University of California at Berkeley. 
Spence, M., 1977. Entry, capacity, investment, and oligopolistic pricing. Bell Journal of Economics 8(2), 534-544.

Spence, M., 1979. Investment strategy and growth in a new market. Bell Journal of Economics 10(1), 1-19.

Spence, M., 1981. The learning curve and competition. Bell Journal of Economics 12(1), 49-70.

Sudarsanam, S., Lai, J., 2001. Corporate financial distress and turnaround strategies: An empirical analysis. British Journal of Management 12, 183-199. 


\section{Appendix A Variable definitions}

\begin{tabular}{|c|c|}
\hline AB_PROD & $\begin{array}{l}\text { is the abnormal production where the normal production is estimated using equation }(1 \mathrm{c}) \text { by } 2 \\
\text { digit industry-year with at least } 15 \text { observations; } \text { AB_PROD }_{\mathrm{ijt}} \text { is PROD } \\
\text { PROD }_{\mathrm{ijt}} \text { minus Nor firm } \mathrm{i} \text { in industry } \mathrm{j} \text { and year } \mathrm{t} \text {. }\end{array}$ \\
\hline AB_RD & $\begin{array}{l}\text { is the abnormal research and development expense where the normal research and development } \\
\text { expense is estimated using equation (1a) by } 2 \text { digit industry-year with at least } 15 \text { observations; } \\
A B \_R D_{i j t} \text { is } R D_{i j t} \text { minus Normal } R D_{i j t} \text { for firm } i \text { in industry } j \text { and year } t \text {. }\end{array}$ \\
\hline AB_RM & $\begin{array}{l}\text { is the abnormal real-activity based earnings management which is abnormal research and } \\
\text { development expense (AB_RD) plus abnormal selling, general and administrative expense } \\
\text { (AB_SGA) minus abnormal production (AB_PROD). }\end{array}$ \\
\hline AB_SGA & $\begin{array}{l}\text { is the abnormal selling, general and administrative expense where the normal selling, general } \\
\text { and administrative expense is estimated using equation }(1 \mathrm{~b}) \text { by } 2 \text { digit industry-year with at } \\
\text { least } 15 \text { observations; AB_SGA } \mathrm{A}_{\mathrm{ijt}} \text { is } \mathrm{SGA}_{\mathrm{ijt}} \text { minus Normal } \mathrm{SGA}_{\mathrm{ijt}} \text { for firm } \mathrm{i} \text { in industry } \mathrm{j} \text { and } \\
\text { year t. }\end{array}$ \\
\hline ADJ_CFO & $\begin{array}{l}\text { is the industry-adjusted cash flow from operations where the industry-year average cash flow } \\
\text { from operations is estimated for every } 2 \text { digit industry-year as total cash flow from operations } \\
\text { in t divided by total assets in } \mathrm{t}-1 \text {; } \mathrm{ADJ} \mathrm{CFO}_{\mathrm{ijt}} \text { is } \mathrm{CFO}_{\mathrm{ijt}} \text { minus industry-year } \mathrm{CFO}_{\mathrm{ijt}} \text { for firm } \mathrm{i} \text { in } \\
\text { industry } \mathrm{j} \text { and year } \mathrm{t} \text {. }\end{array}$ \\
\hline ADJ_ROA & $\begin{array}{l}\text { is the industry-adjusted return on assets where the industry-year average return on assets is } \\
\text { estimated for every } 2 \text { digit industry-year as total income before extraordinary items in t divided } \\
\text { by total assets in } t-1 ; \text { ADJ_ROA }_{\mathrm{ijt}} \text { is } \mathrm{ROA}_{\mathrm{ijt}} \text { minus industry-year } \mathrm{ROA}_{\mathrm{ijt}} \text { for firm i in industry } \mathrm{j} \\
\text { and year } \mathrm{t} \text {. }\end{array}$ \\
\hline ASSET & is the total assets (AT). \\
\hline BEAT & $\begin{array}{l}\text { is an indicator variable equal to } 1 \text { when net income (NI) divided by total assets (AT) is greater } \\
\text { than or equal to } 0.01,0 \text { otherwise. }\end{array}$ \\
\hline $\mathrm{CFO}$ & is the cash flow from operations (OANCF) in t divided by the total assets (AT) in t-1. \\
\hline CH_SALE & is the change in net sales (SALE). \\
\hline CUM_ROA & is the cumulative return on assets which is the sum of ADJ_ROA for the years $t+1, t+2$ and $t+3$. \\
\hline DECLINE & $\begin{array}{l}\text { is an indicator variable equal to } 1 \text { when a firm is not in any of the stages (INTRO, GROWTH } \\
\text { and MATURE), } 0 \text { otherwise. }\end{array}$ \\
\hline GROWTH & $\begin{array}{l}\text { is an indicator variable equal to } 1 \text { when operating cash flows }(\mathrm{OANCF})>0 \text { and investing cash } \\
\text { flows (IVNCF) }<0 \text { and financing cash flows (FINCF) }>0,0 \text { otherwise. }\end{array}$ \\
\hline INCENTIVE & $\begin{array}{l}\text { is an indicator variable equal to one when a firm has a merger or acquisition or it has raised } \\
\text { debt or equity capital, } 0 \text { otherwise. A firm is defined to have raised capital when its long-term } \\
\text { debt (DLTT) has increased by at least } 20 \% \text { or its common shares outstanding (CSHO) have } \\
\text { increased by at least } 10 \% \text {. }\end{array}$ \\
\hline INT & $\begin{array}{l}\text { is the internal funds in } \mathrm{t} \text { divided by total assets (AT) in t-1 where the internal funds is income } \\
\text { before extraordinary items (IB) plus depreciation (DP) plus research and development expense } \\
\text { (XRD). }\end{array}$ \\
\hline INTRO & $\begin{array}{l}\text { is an indicator variable equal to } 1 \text { when operating cash flows }(\mathrm{OANCF})<0 \text { and investing cash } \\
\text { flows (IVNCF) }<0 \text { and financing cash flows (FINCF) }>0,0 \text { otherwise. }\end{array}$ \\
\hline J_BEAT & $\begin{array}{l}\text { is an indicator variable equal to } 1 \text { when net income (NI) divided by total assets (AT) is between } \\
0 \text { and } 0.01,0 \text { otherwise. }\end{array}$ \\
\hline J_MISS & $\begin{array}{l}\text { is an indicator variable equal to } 1 \text { when net income (NI) divided by total assets (AT) is between } \\
-0.01 \text { and } 0,0 \text { otherwise. }\end{array}$ \\
\hline
\end{tabular}




\begin{tabular}{|c|c|}
\hline MATURE & $\begin{array}{l}\text { is an indicator variable equal to } 1 \text { when operating cash flows }(\mathrm{OANCF})>0 \text { and investing cash } \\
\text { flows (IVNCF) }<0 \text { and financing cash flows (FINCF) }<0,0 \text { otherwise. }\end{array}$ \\
\hline MISS & $\begin{array}{l}\text { is an indicator variable equal to } 1 \text { when net income (NI) divided by total assets (AT) is less than } \\
-0.01,0 \text { otherwise. }\end{array}$ \\
\hline MKT_VAL & $\begin{array}{l}\text { is the market value of equity computed as common shares outstanding (CSHO) multiplied by } \\
\text { the fiscal-year end stock price (PRCC_F). }\end{array}$ \\
\hline MTB & is the market value of equity (MKT_VAL) divided by the book value of equity (CEQ). \\
\hline NEG & is an indicator variable equal to 1 when $\mathrm{CH}_{\text {_SALE }}$ is less than zero, 0 otherwise. \\
\hline PROD & $\begin{array}{l}\text { is the production expense in } t \text { divided by the total assets (AT) in t-1 where production expense } \\
\text { is the cost of goods sold (COGS) plus the change in inventory (INVT). }\end{array}$ \\
\hline $\mathrm{RD}$ & is the research and development expense (XRD) in t divided by the total assets (AT) in t- 1 . \\
\hline RETURN & $\begin{array}{l}\text { is the size-adjusted abnormal stock returns computed as the difference in buy and hold returns } \\
\text { for the firm and size matched decile portfolio where buy and hold returns for the firm are } \\
\text { monthly returns (TRT1M) compounded over } 12 \text { months of the fiscal year. }\end{array}$ \\
\hline RM & is an indicator variable equal to 1 when $\mathrm{AB} \_\mathrm{RM}$ is in the lowest quintile, 0 otherwise. \\
\hline ROA & $\begin{array}{l}\text { is the return on assets computed as the income before extraordinary items (IB) in } t \text { divided by } \\
\text { the total assets (AT) in } t-1 \text {. }\end{array}$ \\
\hline SALE & is the net sales (SALE). \\
\hline SGA & Selling, general and administrative expense (XSGA) in t divided by the total assets (AT) in t- 1. \\
\hline TOBIN'S_Q & $\begin{array}{l}\text { is the Tobin's Q computed as the sum of market value of equity (MKT_VAL), preferred stock } \\
\text { (PSTK), long-term debt (DLTT) and debt in current liabilities (DLC) divided by the total assets } \\
\text { (AT). }\end{array}$ \\
\hline ZSCORE & $\begin{array}{l}\text { is a measure of financial health computed using a variant of Altman's }(1968) \mathrm{Z}-\mathrm{Score} \\
\left(\left(3.3 * \mathrm{NI}_{\mathrm{t}} / \mathrm{AT}_{\mathrm{t}-1}\right)+\left(1.0 * \mathrm{SALE}_{\mathrm{t}} / \mathrm{AT}_{\mathrm{t}-1}\right)+\left(1.4 * \mathrm{RE}_{\mathrm{t}} / \mathrm{AT}_{\mathrm{t}-1}\right)+\left(\left(1.2 *\left(\mathrm{ACT}_{\mathrm{t}}-\mathrm{LCT}_{\mathrm{t}}\right) / \mathrm{AT}_{\mathrm{t}-1}\right)\right) \text {. }\right.\end{array}$ \\
\hline
\end{tabular}




\section{Appendix B Estimation of real-activity based earnings management measures}

To estimate equation (1a) we use all available observations in the Compustat database with nonmissing R\&D expenses from years 1987 to 2014 for each industry-year. The number of firm-year observations for the estimation is 87,186, representing 554 industry-years. The mean of the industry-year estimates is provided below the variable and the t-statistic based on the mean is in parenthesis. *,**, and $* * *$ denote p-values at $10 \%, 5 \%$ and $1 \%$ for a two-tailed test.

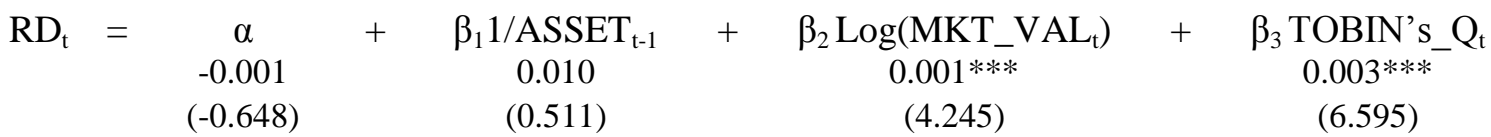

$$
\begin{aligned}
& \beta_{4} \mathrm{INT}_{\mathrm{t}} \quad \beta_{5} \mathrm{RD}_{\mathrm{t}-1} \\
& 0.006 * \quad 0.946 * * * \\
& \text { (1.843) (78.372) }
\end{aligned}
$$

The mean adjusted $\mathrm{R}^{2}$ of the industry-year estimations is $90.1 \%$.

To estimate equation (1b) we use all available observations in the Compustat database with nonmissing SGA expenses from years 1987 to 2014 for each industry-year. The number of firm-year observations used in the estimation is 141,651, representing 1,211 industry-years. The mean of the industry-year estimates is provided below the variable and the t-statistic based on the mean is in parenthesis. $*, * *$, and $* * *$ denote p-values at $10 \%, 5 \%$ and $1 \%$ for a two-tailed test.

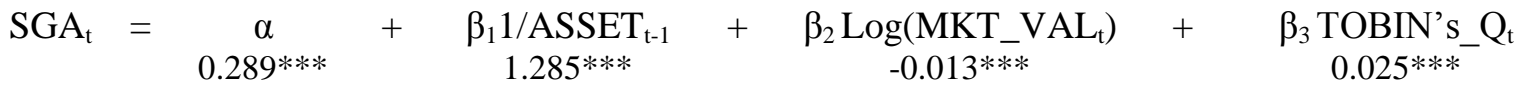

$$
\begin{aligned}
& \text { (41.742) (6.418) } \quad(-13.976)
\end{aligned}
$$

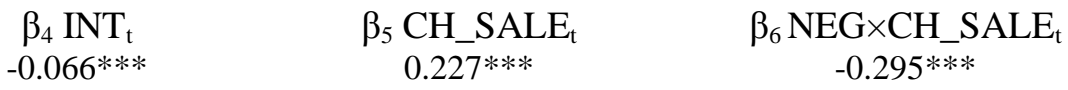

$$
\begin{aligned}
& (-3.561) \quad(21.082)
\end{aligned}
$$

The mean adjusted $\mathrm{R}^{2}$ of the industry-year estimations is $60.9 \%$.

To estimate equation (1c) we use all available observations in the Compustat database with nonmissing production expenses from years 1987 to 2014 for each industry-year. The number of firm-year observations used in the estimation is 147,187, representing 1,237 industry-years. The mean of the industry-year estimates is provided below the variable and the t-statistic based on the mean is in parenthesis. *,**, and $* * *$ denote p-values at $10 \%, 5 \%$ and $1 \%$ for a two-tailed test.

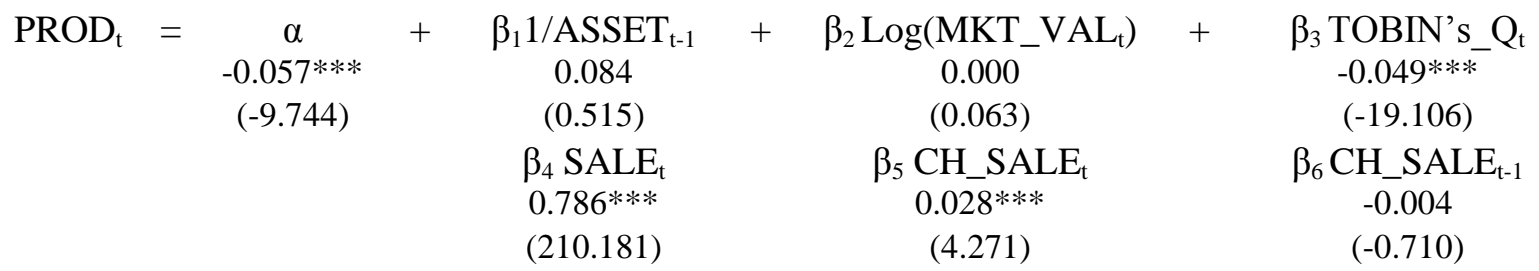

The mean adjusted $\mathrm{R}^{2}$ of the industry-year estimations is $90.0 \%$. 
Table 1: Avoiding losses and real-activity based earnings management

Panel A: Descriptive statistics

\begin{tabular}{|c|c|c|c|c|c|c|c|c|c|c|}
\hline 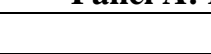 & \multicolumn{5}{|c|}{ Mean } & \multicolumn{5}{|c|}{ Median } \\
\hline & All stages & Intro & Growth & Mature & Decline & All stages & Intro & Growth & Mature & Decline \\
\hline AB_RM & 0.068 & 0.056 & 0.113 & 0.072 & 0.003 & 0.005 & -0.037 & 0.032 & 0.023 & -0.048 \\
\hline $\log \left(\operatorname{ASSET}_{t}\right)$ & 5.001 & 3.294 & 5.559 & 5.895 & 4.215 & 4.858 & 3.259 & 5.442 & 5.838 & 4.016 \\
\hline $\mathrm{MTB}_{\mathrm{t}}$ & 3.471 & 4.962 & 3.372 & 2.872 & 3.185 & 2.022 & 2.308 & 2.283 & 1.932 & 1.613 \\
\hline $\mathrm{ROA}_{\mathrm{t}}$ & -0.121 & -0.611 & 0.052 & 0.058 & -0.204 & 0.029 & -0.240 & 0.059 & 0.059 & -0.072 \\
\hline \# of obs. & 60,151 & 11,774 & 16,268 & 21,585 & 10,524 & 60,151 & 11,774 & 16,268 & 21,585 & 10,524 \\
\hline
\end{tabular}

Panel B: Results of estimating equation (2)

\begin{tabular}{|c|c|c|c|c|c|c|c|c|c|c|}
\hline & All stages & Intro & Growth & Mature & Decline & All stages & Intro & Growth & Mature & Decline \\
\hline & $\begin{array}{l}\text { Coefficient } \\
\text { (t-statistic) }\end{array}$ & $\begin{array}{c}\text { Coefficient } \\
\text { (t-statistic) }\end{array}$ & $\begin{array}{c}\text { Coefficient } \\
\text { (t-statistic) }\end{array}$ & $\begin{array}{l}\text { Coefficient } \\
\text { (t-statistic) }\end{array}$ & $\begin{array}{c}\text { Coefficient } \\
\text { (t-statistic) }\end{array}$ & $\begin{array}{l}\text { Coefficient } \\
\text { (t-statistic) }\end{array}$ & $\begin{array}{l}\text { Coefficient } \\
\text { (t-statistic) }\end{array}$ & $\begin{array}{l}\text { Coefficient } \\
\text { (t-statistic) }\end{array}$ & $\begin{array}{c}\text { Coefficient } \\
\text { (t-statistic) }\end{array}$ & $\begin{array}{l}\text { Coefficient } \\
\text { (t-statistic) }\end{array}$ \\
\hline $\mathbf{J}_{-} \mathbf{B E A T}_{\mathbf{t}}$ & $\begin{array}{c}-\mathbf{- 0 . 0 7 8 * * * *} \\
(-9.710)\end{array}$ & $\begin{array}{c}0.016 \\
(0.776)\end{array}$ & $\begin{array}{c}-\mathbf{0 . 0 6 3} * * * \\
(-4.830)\end{array}$ & $\begin{array}{c}-0.042 * * * \\
(-2.963)\end{array}$ & $\begin{array}{c}-0.055 * * * \\
(-3.147)\end{array}$ & $\begin{array}{c}-0.035 * * * \\
(-4.389)\end{array}$ & $\begin{array}{l}0.034 * \\
(1.662)\end{array}$ & $\begin{array}{c}-0.050 * * * \\
(-3.934)\end{array}$ & $\begin{array}{c}-0.040 * * * \\
(-3.341)\end{array}$ & $\begin{array}{c}0.002 \\
(0.107)\end{array}$ \\
\hline $\mathrm{J}_{-} \mathrm{MISS}_{\mathrm{t}}$ & $\begin{array}{c}-0.101 * * * \\
(-10.481)\end{array}$ & $\begin{array}{c}-0.067 * * \\
(-2.346)\end{array}$ & $\begin{array}{c}-0.077 * * * \\
(-4.708)\end{array}$ & $\begin{array}{l}-0.034 * \\
(-1.835)\end{array}$ & $\begin{array}{c}-0.092 * * * \\
(-6.725)\end{array}$ & - & - & - & - & - \\
\hline $\mathrm{MISS}_{\mathrm{t}}$ & $\begin{array}{c}-0.130 * * * \\
(-13.026)\end{array}$ & $\begin{array}{c}-0.039 * * \\
(-2.239)\end{array}$ & $\begin{array}{c}-0.042 * * * \\
(-2.651)\end{array}$ & $\begin{array}{c}-0.009 \\
(-0.439)\end{array}$ & $\begin{array}{c}-0.108 * * * \\
(-8.936)\end{array}$ & - & - & - & - & - \\
\hline $\log \left(\mathrm{ASSET}_{\mathrm{t}}\right)$ & $\begin{array}{c}-0.034 * * * \\
(-12.456)\end{array}$ & $\begin{array}{c}-0.042 * * * \\
(-9.193)\end{array}$ & $\begin{array}{c}-0.049 * * * \\
(-13.959)\end{array}$ & $\begin{array}{c}-0.034 * * * \\
(-12.109)\end{array}$ & $\begin{array}{c}-0.033 * * * \\
(-8.384)\end{array}$ & $\begin{array}{c}-0.027 * * * \\
(-11.074)\end{array}$ & $\begin{array}{c}-0.042 * * * \\
(-8.978)\end{array}$ & $\begin{array}{c}-0.048 * * * \\
(-14.042)\end{array}$ & $\begin{array}{c}-0.033 * * * \\
(-12.370)\end{array}$ & $\begin{array}{c}-0.028 * * * \\
(-7.214)\end{array}$ \\
\hline $\mathrm{MTB}_{\mathrm{t}}$ & $\begin{array}{c}0.006 * * * \\
(7.120)\end{array}$ & $\begin{array}{c}0.001 \\
(1.386)\end{array}$ & $\begin{array}{c}0.013 * * * \\
(5.673)\end{array}$ & $\begin{array}{c}0.009 * * * \\
(6.533)\end{array}$ & $\begin{array}{c}0.004 * * * \\
(3.279)\end{array}$ & $\begin{array}{c}0.007 * * * \\
(7.618)\end{array}$ & $\begin{array}{l}0.002 * \\
(1.889)\end{array}$ & $\begin{array}{c}0.014 * * * \\
(6.024)\end{array}$ & $\begin{array}{c}0.009 * * * \\
(6.692)\end{array}$ & $\begin{array}{c}0.004 * * * \\
(3.234)\end{array}$ \\
\hline $\mathrm{ROA}_{\mathrm{t}}$ & $\begin{array}{l}0.026^{*} \\
(1.836)\end{array}$ & $\begin{array}{c}-0.015 \\
(-0.926)\end{array}$ & $\begin{array}{c}0.136 * * * \\
(2.731)\end{array}$ & $\begin{array}{c}0.481 * * * \\
(5.714)\end{array}$ & $\begin{array}{c}0.082 * * * \\
(3.538)\end{array}$ & $\begin{array}{c}0.087 * * * \\
(6.745)\end{array}$ & $\begin{array}{c}0.018 \\
(1.387)\end{array}$ & $\begin{array}{c}0.177 * * * \\
(3.963)\end{array}$ & $\begin{array}{c}0.488 * * * \\
(8.924)\end{array}$ & $\begin{array}{c}0.125^{* * * *} \\
(5.254)\end{array}$ \\
\hline Adj $R^{2}$ & $5.0 \%$ & $3.1 \%$ & $11.3 \%$ & $9.6 \%$ & $5.0 \%$ & $5.0 \%$ & $3.1 \%$ & $11.3 \%$ & $9.6 \%$ & $5.0 \%$ \\
\hline \# of obs. & 60,151 & 11,774 & 16,268 & 21,585 & 10,524 & 60,151 & 11,774 & 16,268 & 21,585 & 10,524 \\
\hline
\end{tabular}

\section{Notes to Table 1}

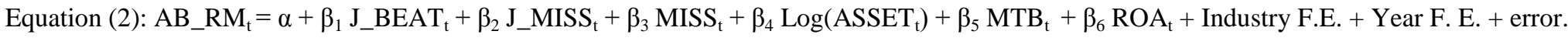

1. The standard errors for computing t-statistics are corrected using firm and year clusters.

2. $*, * *$, and $* * *$ denote $\mathrm{p}$-values at $10 \%, 5 \%$ and $1 \%$ for a two-tailed test.

3. Variable definitions are in Appendix A. 
Table 2: Future return on assets, avoiding losses and real-activity based earnings management

Panel A: Descriptive statistics

\begin{tabular}{|c|c|c|c|c|c|c|c|c|c|c|}
\hline & \multicolumn{5}{|c|}{ Mean } & \multicolumn{5}{|c|}{ Median } \\
\hline & All stages & Intro & Growth & Mature & Decline & All stages & Intro & Growth & Mature & Decline \\
\hline ADJ_ROA & -0.166 & -0.655 & 0.006 & 0.010 & -0.245 & -0.019 & -0.284 & 0.012 & 0.010 & -0.115 \\
\hline RETURN $_{\mathrm{t}}$ & 0.825 & 1.726 & 1.197 & 0.335 & 0.245 & -0.080 & -0.116 & -0.026 & -0.075 & -0.182 \\
\hline $\mathrm{ZSCORE}_{\mathrm{t}}$ & -0.600 & -7.122 & 1.854 & 1.947 & -2.321 & 1.683 & -1.358 & 2.165 & 2.157 & 0.271 \\
\hline \# of obs. & 60,151 & 11,774 & 16,268 & 21,585 & 10,524 & 60,151 & 11,774 & 16,268 & 21,585 & 10,524 \\
\hline
\end{tabular}

Panel B: Results of estimating equation (3)

\begin{tabular}{|c|c|c|c|c|c|c|c|c|c|c|}
\hline & All stages & Intro & Growth & Mature & Decline & All stages & Intro & Growth & Mature & Decline \\
\hline & $\begin{array}{l}\text { Coefficient } \\
\text { (t-statistic) }\end{array}$ & $\begin{array}{l}\text { Coefficient } \\
\text { (t-statistic) }\end{array}$ & $\begin{array}{l}\text { Coefficient } \\
\text { (t-statistic) }\end{array}$ & $\begin{array}{l}\text { Coefficient } \\
\text { (t-statistic) }\end{array}$ & $\begin{array}{l}\text { Coefficient } \\
\text { (t-statistic) }\end{array}$ & $\begin{array}{l}\text { Coefficient } \\
\text { (t-statistic) }\end{array}$ & $\begin{array}{l}\text { Coefficient } \\
\text { (t-statistic) }\end{array}$ & $\begin{array}{l}\text { Coefficient } \\
\text { (t-statistic) }\end{array}$ & $\begin{array}{l}\text { Coefficient } \\
\text { (t-statistic) }\end{array}$ & $\begin{array}{l}\text { Coefficient } \\
\text { (t-statistic) }\end{array}$ \\
\hline $\mathrm{J}_{-} \mathrm{BEAT}_{\mathrm{t}}$ & $\begin{array}{c}-0.038 * * * \\
(-10.115)\end{array}$ & $\begin{array}{c}-0.013 \\
(-0.923)\end{array}$ & $\begin{array}{c}-0.039 * * * \\
(-6.521)\end{array}$ & $\begin{array}{c}-0.039 * * * \\
(-8.318)\end{array}$ & $\begin{array}{c}-0.015 \\
(-1.196)\end{array}$ & $\begin{array}{c}-0.040 * * * \\
(-10.441)\end{array}$ & $\begin{array}{c}-0.022 \\
(-1.573)\end{array}$ & $\begin{array}{c}-0.039 * * * \\
(-6.527)\end{array}$ & $\begin{array}{c}-0.038 * * * \\
(-8.116)\end{array}$ & $\begin{array}{c}-0.019 \\
(-1.449)\end{array}$ \\
\hline $\mathrm{J}_{-} \mathrm{MISS}_{\mathrm{t}}$ & $\begin{array}{c}-0.030 * * * \\
(-6.335)\end{array}$ & $\begin{array}{l}-0.037 * \\
(-1.868)\end{array}$ & $\begin{array}{c}-0.023 * * * \\
(-2.945)\end{array}$ & $\begin{array}{c}-0.031 * * * \\
(-5.917)\end{array}$ & $\begin{array}{l}-0.028 * \\
(-1.939)\end{array}$ & $\begin{array}{c}-0.028 * * * \\
(-6.346)\end{array}$ & $\begin{array}{c}-0.024 \\
(-1.480)\end{array}$ & $\begin{array}{c}-0.025 * * * \\
(-3.254)\end{array}$ & $\begin{array}{c}-0.029 * * * \\
(-5.209)\end{array}$ & $\begin{array}{c}-0.025 * * \\
(-2.113)\end{array}$ \\
\hline $\mathrm{MISS}_{\mathrm{t}}$ & $\begin{array}{c}-0.044 * * * \\
(-7.519)\end{array}$ & $\begin{array}{c}-0.015 \\
(-1.253)\end{array}$ & $\begin{array}{c}-0.024 * * * \\
(-2.658)\end{array}$ & $\begin{array}{c}-0.023^{* * * *} \\
(-4.022)\end{array}$ & $\begin{array}{c}-0.030 * * * \\
(-4.881)\end{array}$ & $\begin{array}{c}-0.048 * * * \\
(-8.308)\end{array}$ & $\begin{array}{c}-0.026 * * * \\
(-2.725)\end{array}$ & $\begin{array}{c}-0.022 * * \\
(-2.569)\end{array}$ & $\begin{array}{c}-0.019 * * * \\
(-3.564)\end{array}$ & $\begin{array}{c}-0.036 * * * \\
(-5.760)\end{array}$ \\
\hline $\mathrm{RM}_{\mathrm{t}}$ & $\begin{array}{c}-0.013 * * * \\
(-5.865)\end{array}$ & $\begin{array}{c}-0.012 \\
(-1.158)\end{array}$ & $\begin{array}{l}-0.006^{*} \\
(-1.872)\end{array}$ & $\begin{array}{c}-0.009 * * * \\
(-4.615)\end{array}$ & $\begin{array}{c}-0.005 \\
(-0.513)\end{array}$ & $\begin{array}{c}-0.022 * * * \\
(-6.707)\end{array}$ & $\begin{array}{c}-0.042 * * * \\
(-5.427)\end{array}$ & $\begin{array}{c}-0.004 \\
(-1.239)\end{array}$ & $\begin{array}{c}-0.005 * * \\
(-2.129)\end{array}$ & $\begin{array}{c}-0.026 * * * \\
(-3.390)\end{array}$ \\
\hline $\mathbf{R M}_{t} \times \mathbf{J}_{-} \mathbf{B E A T} \mathbf{T}_{\mathrm{t}}$ & $\begin{array}{l}0.012 * \\
(1.806)\end{array}$ & $\begin{array}{c}-0.004 \\
(-0.181)\end{array}$ & $\begin{array}{c}0.017 * \\
(1.867)\end{array}$ & $\begin{array}{c}0.025 * * * \\
(2.981)\end{array}$ & $\begin{array}{c}-0.032 \\
(-1.486)\end{array}$ & $\begin{array}{c}0.021 * * * \\
(2.866)\end{array}$ & $\begin{array}{c}\mathbf{0 . 0 2 7} \\
(\mathbf{1 . 3 1 5})\end{array}$ & $\begin{array}{c}0.015 \\
(1.567)\end{array}$ & $\begin{array}{c}0.020 * * \\
(2.365)\end{array}$ & $\begin{array}{c}-0.010 \\
(-0.439)\end{array}$ \\
\hline $\mathrm{RM}_{\mathrm{t}} \times \mathrm{J} \_\mathrm{MISS}_{\mathrm{t}}$ & $\begin{array}{c}0.008 \\
(0.799)\end{array}$ & $\begin{array}{c}0.045 \\
(0.983)\end{array}$ & $\begin{array}{c}-0.006 \\
(-0.423)\end{array}$ & $\begin{array}{c}0.011 \\
(0.885)\end{array}$ & $\begin{array}{c}0.006 \\
(0.191)\end{array}$ & - & - & - & - & - \\
\hline $\mathrm{RM}_{\mathrm{t}} \times \mathrm{MISS}_{\mathrm{t}}$ & $\begin{array}{c}-0.022 * * * \\
(-2.969)\end{array}$ & $\begin{array}{c}-0.042 * * * \\
(-2.577)\end{array}$ & $\begin{array}{c}0.011 \\
(1.194)\end{array}$ & $\begin{array}{c}0.018 * * * \\
(2.854)\end{array}$ & $\begin{array}{l}-0.032 * * \\
(-2.152)\end{array}$ & - & - & - & - & - \\
\hline ADJ_ROA & $\begin{array}{l}0.391 * * * \\
(14.042)\end{array}$ & $\begin{array}{c}0.343 * * * \\
(13.966)\end{array}$ & $\begin{array}{c}0.308 * * * \\
(7.257)\end{array}$ & $\begin{array}{c}0.435^{* * * *} \\
(12.850)\end{array}$ & $\begin{array}{c}0.445 * * * \\
(12.692)\end{array}$ & $\begin{array}{c}0.392 * * * \\
(14.022)\end{array}$ & $\begin{array}{c}0.345^{* * *} * \\
(13.788)\end{array}$ & $\begin{array}{c}0.308 * * * \\
(7.255)\end{array}$ & $\begin{array}{c}0.435 * * * \\
(12.906)\end{array}$ & $\begin{array}{c}0.445 * * * \\
(12.780)\end{array}$ \\
\hline $\log \left(\mathrm{ASSET}_{\mathrm{t}}\right)$ & $\begin{array}{c}0.016 * * * \\
(15.737)\end{array}$ & $\begin{array}{c}0.044 * * * \\
(14.197)\end{array}$ & $\begin{array}{c}0.005 * * * \\
(6.292)\end{array}$ & $\begin{array}{c}0.003 * * * \\
(5.173)\end{array}$ & $\begin{array}{c}0.024 * * * \\
(10.393)\end{array}$ & $\begin{array}{c}0.016 * * * \\
(15.715)\end{array}$ & $\begin{array}{c}0.044 * * * \\
(14.434)\end{array}$ & $\begin{array}{c}0.005 * * * \\
(6.273)\end{array}$ & $\begin{array}{c}0.003 * * * \\
(5.187)\end{array}$ & $\begin{array}{c}0.024 * * * \\
(10.437)\end{array}$ \\
\hline $\mathrm{MTB}_{\mathrm{t}}$ & $\begin{array}{c}-0.002 * * * \\
(-4.717)\end{array}$ & $\begin{array}{c}-0.004 * * * \\
(-5.183)\end{array}$ & $\begin{array}{c}0.003 * * * \\
(2.737)\end{array}$ & $\begin{array}{c}0.003 * * * \\
(6.660)\end{array}$ & $\begin{array}{c}-0.004 * * * \\
(-3.129)\end{array}$ & $\begin{array}{c}-0.002 * * * \\
(-4.724)\end{array}$ & $\begin{array}{c}-0.004 * * * \\
(-5.220)\end{array}$ & $\begin{array}{c}0.003 * * * \\
(2.735)\end{array}$ & $\begin{array}{c}0.003 * * * \\
(6.709)\end{array}$ & $\begin{array}{c}-0.004 * * * \\
(-3.106)\end{array}$ \\
\hline RETURN $_{\mathrm{t}}$ & $\begin{array}{c}0.001 * * * \\
(3.918)\end{array}$ & $\begin{array}{c}0.002 * * * \\
(4.267)\end{array}$ & $\begin{array}{l}-0.001 * * \\
(-2.115)\end{array}$ & $\begin{array}{c}0.000 \\
(1.476)\end{array}$ & $\begin{array}{c}0.000 \\
(0.390)\end{array}$ & $\begin{array}{c}0.001 * * * \\
(3.937)\end{array}$ & $\begin{array}{c}0.002 * * * \\
(4.278)\end{array}$ & $\begin{array}{l}-0.001 * * \\
(-2.112)\end{array}$ & $\begin{array}{c}0.000 \\
(1.472)\end{array}$ & $\begin{array}{c}0.000 \\
(0.416)\end{array}$ \\
\hline $\mathrm{ZSCORE}_{\mathrm{t}}$ & $\begin{array}{c}0.011 * * * \\
(9.425) \\
\end{array}$ & $\begin{array}{c}0.012 * * * \\
(9.106)\end{array}$ & $\begin{array}{c}0.010 * * * \\
(4.328) \\
\end{array}$ & $\begin{array}{c}0.007 * * * \\
(3.420) \\
\end{array}$ & $\begin{array}{c}0.009 * * * \\
(6.090) \\
\end{array}$ & $\begin{array}{c}0.011 * * * \\
(9.488) \\
\end{array}$ & $\begin{array}{c}0.012 * * * \\
(9.216) \\
\end{array}$ & $\begin{array}{c}0.010 * * * \\
(4.328) \\
\end{array}$ & $\begin{array}{c}0.007 * * * \\
(3.436) \\
\end{array}$ & $\begin{array}{c}0.009 * * * \\
(6.155) \\
\end{array}$ \\
\hline $\operatorname{Adj~R}{ }^{2}$ & $67.4 \%$ & $70.4 \%$ & $29.3 \%$ & $30.3 \%$ & $55.7 \%$ & $67.4 \%$ & $70.3 \%$ & $29.3 \%$ & $30.2 \%$ & $55.7 \%$ \\
\hline \# of obs. & 60,151 & 11,774 & 16,268 & 21,585 & 10,524 & 60,151 & 11,774 & 16,268 & 21,585 & 10,524 \\
\hline
\end{tabular}

Notes to Table 2 
Equation (3): ADJ_ROA ${ }_{t+1}=\alpha+\beta_{1} J_{-} B E A T_{t}+\beta_{2} J_{-}$MISS $_{t}+\beta_{3}$ MISS $_{t}+\beta_{4} \mathrm{RM}_{t}+\beta_{5} \mathrm{RM}_{t} \times \mathrm{J}_{-} \mathrm{BEAT}_{\mathrm{t}}+\beta_{6} \mathrm{RM}_{\mathrm{t}} \times \mathrm{J}_{-} \mathrm{MISS}_{\mathrm{t}}+\beta_{7} \mathrm{RM}_{\mathrm{t}} \times \mathrm{MISS}$

$+\beta_{8}$ ADJ_ROA ${ }_{t}+\beta_{9} \log \left(\right.$ ASSET $\left._{t}\right)+\beta_{10}$ MTB $_{t}+\beta_{11}$ RETURN $_{t}+\beta_{12}$ ZSCORE $_{t}+$ Industry F.E. + Year F. E. + error.

1. The standard errors for computing t-statistics are corrected using firm and year clusters.

2. *,**, and *** denote $\mathrm{p}$-values at $10 \%, 5 \%$ and $1 \%$ for a two-tailed test.

3. Variable definitions are in Appendix A. 
Table 3 Alternative measures of future performance, avoiding losses and real-activity based earnings management

Panel A: Future performance $=\mathrm{CFO}_{\mathrm{t}+1}$

\begin{tabular}{|c|c|c|c|c|c|c|c|c|c|c|}
\hline & All stages & Intro & Growth & Mature & Decline & All stages & Intro & Growth & Mature & Decline \\
\hline & $\begin{array}{l}\text { Coefficient } \\
\text { (t-statistic) }\end{array}$ & $\begin{array}{l}\text { Coefficient } \\
\text { (t-statistic) }\end{array}$ & $\begin{array}{l}\text { Coefficient } \\
\text { (t-statistic) }\end{array}$ & $\begin{array}{l}\text { Coefficient } \\
\text { (t-statistic) }\end{array}$ & $\begin{array}{l}\text { Coefficient } \\
\text { (t-statistic) }\end{array}$ & $\begin{array}{l}\text { Coefficient } \\
\text { (t-statistic) }\end{array}$ & $\begin{array}{l}\text { Coefficient } \\
\text { (t-statistic) }\end{array}$ & $\begin{array}{l}\text { Coefficient } \\
\text { (t-statistic) }\end{array}$ & $\begin{array}{l}\text { Coefficient } \\
\text { (t-statistic) }\end{array}$ & $\begin{array}{l}\text { Coefficient } \\
\text { (t-statistic) }\end{array}$ \\
\hline $\mathrm{J}_{\mathrm{BEAT}} \mathrm{BEA}_{\mathrm{t}}$ & $\begin{array}{c}-0.030 * * * \\
(-9.955)\end{array}$ & $\begin{array}{c}0.009 \\
(0.958)\end{array}$ & $\begin{array}{c}-0.030 * * * \\
(-7.313)\end{array}$ & $\begin{array}{c}-0.022 * * * \\
(-4.867)\end{array}$ & $\begin{array}{c}-0.014 \\
(-1.511)\end{array}$ & $\begin{array}{c}-0.030 * * * \\
(-10.133)\end{array}$ & $\begin{array}{c}0.011 \\
(1.236)\end{array}$ & $\begin{array}{c}-0.030 * * * \\
(-7.153)\end{array}$ & $\begin{array}{c}-0.022 * * * \\
(-4.943)\end{array}$ & $\begin{array}{l}-0.017 * \\
(-1.844)\end{array}$ \\
\hline $\mathrm{J}_{-} \mathrm{MISS}_{\mathrm{t}}$ & $\begin{array}{c}-0.028 * * * \\
(-8.935)\end{array}$ & $\begin{array}{c}-0.006 \\
(-0.370)\end{array}$ & $\begin{array}{c}-0.027 * * * \\
(-5.085)\end{array}$ & $\begin{array}{c}-0.021 * * * \\
(-4.903)\end{array}$ & $\begin{array}{c}-0.010 \\
(-1.105)\end{array}$ & $\begin{array}{c}-0.023 * * * \\
(-6.958)\end{array}$ & $\begin{array}{c}0.010 \\
(0.687)\end{array}$ & $\begin{array}{c}-0.024 * * * \\
(-4.703)\end{array}$ & $\begin{array}{c}-0.018 * * * \\
(-4.893)\end{array}$ & $\begin{array}{c}-0.005 \\
(-0.647)\end{array}$ \\
\hline $\mathrm{MISS}_{\mathrm{t}}$ & $\begin{array}{c}-0.056 * * * \\
(-10.222)\end{array}$ & $\begin{array}{c}-0.033 * * * \\
(-4.042)\end{array}$ & $\begin{array}{c}-0.017 * * * \\
(-4.040)\end{array}$ & $\begin{array}{c}0.001 \\
(0.114)\end{array}$ & $\begin{array}{c}-0.035 * * * \\
(-5.309)\end{array}$ & $\begin{array}{c}-0.058 * * * \\
(-10.648)\end{array}$ & $\begin{array}{c}-0.031 * * * \\
(-4.268)\end{array}$ & $\begin{array}{c}-0.015 * * * \\
(-3.665)\end{array}$ & $\begin{array}{c}0.001 \\
(0.212)\end{array}$ & $\begin{array}{c}-0.040 * * * \\
(-6.234)\end{array}$ \\
\hline $\mathrm{RM}_{\mathrm{t}}$ & $\begin{array}{l}-0.031 * * * \\
(-12.573)\end{array}$ & $\begin{array}{c}-0.036 * * * \\
(-4.084)\end{array}$ & $\begin{array}{c}-0.024 * * * \\
(-6.900)\end{array}$ & $\begin{array}{c}-0.021 * * * \\
(-7.562)\end{array}$ & $\begin{array}{c}-0.022 * * * \\
(-2.614)\end{array}$ & $\begin{array}{c}-0.033 * * * \\
(-11.643)\end{array}$ & $\begin{array}{c}-0.030 * * * \\
(-5.050)\end{array}$ & $\begin{array}{c}-0.021 * * * \\
(-5.499)\end{array}$ & $\begin{array}{c}-0.020 * * * \\
(-7.393)\end{array}$ & $\begin{array}{c}-0.041 * * * \\
(-7.571)\end{array}$ \\
\hline $\mathbf{R M}_{\mathrm{t}} \times \mathbf{J} \_\mathbf{B E A T}_{\mathrm{t}}$ & $\begin{array}{c}0.015 * * \\
(2.541)\end{array}$ & $\begin{array}{c}-0.010 \\
(-0.520)\end{array}$ & $\begin{array}{c}0.026 * * * \\
(3.913)\end{array}$ & $\begin{array}{c}0.018 * * \\
(2.158)\end{array}$ & $\begin{array}{c}-0.004 \\
(-0.305)\end{array}$ & $\begin{array}{c}0.017 * * * \\
(2.718)\end{array}$ & $\begin{array}{c}-0.016 \\
(-0.836)\end{array}$ & $\begin{array}{c}0.022 * * * \\
(3.178)\end{array}$ & $\begin{array}{l}0.017 * * \\
(2.120)\end{array}$ & $\begin{array}{c}0.014 \\
(0.960)\end{array}$ \\
\hline $\mathrm{RM}_{\mathrm{t}} \times \mathrm{J} \_\mathrm{MISS}_{\mathrm{t}}$ & $\begin{array}{c}0.022 * * * \\
(3.646)\end{array}$ & $\begin{array}{c}0.055 * * \\
(2.276)\end{array}$ & $\begin{array}{c}0.018 * * * \\
(2.755)\end{array}$ & $\begin{array}{c}0.012 \\
(1.547)\end{array}$ & $\begin{array}{c}0.013 \\
(0.704)\end{array}$ & - & - & - & - & - \\
\hline $\mathrm{RM}_{\mathrm{t}} \times \mathrm{MISS}_{\mathrm{t}}$ & $\begin{array}{c}-0.006 \\
(-1.117)\end{array}$ & $\begin{array}{c}0.006 \\
(0.571)\end{array}$ & $\begin{array}{c}0.011 \\
(1.564)\end{array}$ & $\begin{array}{c}0.003 \\
(0.396)\end{array}$ & $\begin{array}{l}-0.027 * * \\
(-2.411)\end{array}$ & - & - & - & - & - \\
\hline Controls & Yes & Yes & Yes & Yes & Yes & Yes & Yes & Yes & Yes & Yes \\
\hline $\operatorname{Adj~R}{ }^{2}$ & $61.6 \%$ & $65.3 \%$ & $16.8 \%$ & $22.5 \%$ & $52.6 \%$ & $61.6 \%$ & $65.3 \%$ & $16.7 \%$ & $22.5 \%$ & $52.6 \%$ \\
\hline \# of obs. & 60,151 & 11,774 & 16,268 & 21,585 & 10,524 & 60,151 & 11,774 & 16,268 & 21,585 & 10,524 \\
\hline
\end{tabular}


Panel B: Future performance = Future three years' cumulative industry-adjusted ROA

\begin{tabular}{|c|c|c|c|c|c|c|c|c|c|c|}
\hline & All stages & Intro & Growth & Mature & Decline & All stages & Intro & Growth & Mature & Decline \\
\hline & $\begin{array}{l}\text { Coefficient } \\
\text { (t-statistic) }\end{array}$ & $\begin{array}{l}\text { Coefficient } \\
\text { (t-statistic) }\end{array}$ & $\begin{array}{c}\text { Coefficient } \\
\text { (t-statistic) }\end{array}$ & $\begin{array}{l}\text { Coefficient } \\
\text { (t-statistic) }\end{array}$ & $\begin{array}{l}\text { Coefficient } \\
\text { (t-statistic) }\end{array}$ & $\begin{array}{l}\text { Coefficient } \\
\text { (t-statistic) }\end{array}$ & $\begin{array}{l}\text { Coefficient } \\
\text { (t-statistic) }\end{array}$ & $\begin{array}{l}\text { Coefficient } \\
\text { (t-statistic) }\end{array}$ & $\begin{array}{l}\text { Coefficient } \\
\text { (t-statistic) }\end{array}$ & $\begin{array}{l}\text { Coefficient } \\
\text { (t-statistic) }\end{array}$ \\
\hline $\mathrm{J}_{-} \mathrm{BEAT}_{\mathrm{t}}$ & $\begin{array}{c}-0.062 * * * \\
(-7.541)\end{array}$ & $\begin{array}{c}-0.015 \\
(-0.397)\end{array}$ & $\begin{array}{c}-0.058 * * * \\
(-2.746)\end{array}$ & $\begin{array}{c}-0.088 * * * \\
(-6.982)\end{array}$ & $\begin{array}{c}-0.031 \\
(-1.065)\end{array}$ & $\begin{array}{c}-0.065 * * * \\
(-7.814)\end{array}$ & $\begin{array}{c}-0.039 \\
(-1.025)\end{array}$ & $\begin{array}{c}-0.057 * * * \\
(-2.694)\end{array}$ & $\begin{array}{c}-0.086 * * * \\
(-6.805)\end{array}$ & $\begin{array}{c}-0.044 \\
(-1.538)\end{array}$ \\
\hline $\mathrm{J}_{-} \mathrm{MISS}_{\mathrm{t}}$ & $\begin{array}{c}-0.036 * * \\
(-2.477)\end{array}$ & $\begin{array}{c}-0.015 \\
(-0.304)\end{array}$ & $\begin{array}{l}-0.056^{*} \\
(-1.889)\end{array}$ & $\begin{array}{c}-0.050 * * * \\
(-2.756)\end{array}$ & $\begin{array}{c}0.003 \\
(0.084)\end{array}$ & $\begin{array}{c}-0.031 * * \\
(-2.199)\end{array}$ & $\begin{array}{c}-0.004 \\
(-0.090)\end{array}$ & $\begin{array}{c}-0.060 * * \\
(-2.218)\end{array}$ & $\begin{array}{c}-0.046 * * * \\
(-2.717)\end{array}$ & $\begin{array}{c}0.012 \\
(0.398)\end{array}$ \\
\hline $\mathrm{MISS}_{\mathrm{t}}$ & $\begin{array}{c}-0.041 * * * \\
(-2.902)\end{array}$ & $\begin{array}{l}0.048 * \\
(1.684)\end{array}$ & $\begin{array}{c}-0.019 \\
(-0.520)\end{array}$ & $\begin{array}{l}-0.024^{*} \\
(-1.880)\end{array}$ & $\begin{array}{c}-0.011 \\
(-0.397)\end{array}$ & $\begin{array}{c}-0.052 * * * \\
(-3.325)\end{array}$ & $\begin{array}{c}0.016 \\
(0.604)\end{array}$ & $\begin{array}{c}-0.011 \\
(-0.291)\end{array}$ & $\begin{array}{l}-0.013 \\
(-0.966)\end{array}$ & $\begin{array}{c}-0.034 \\
(-1.255)\end{array}$ \\
\hline $\mathrm{RM}_{\mathrm{t}}$ & $\begin{array}{c}-0.032 * * * \\
(-4.970)\end{array}$ & $\begin{array}{c}-0.004 \\
(-0.158)\end{array}$ & $\begin{array}{l}-0.015^{*} \\
(-1.694)\end{array}$ & $\begin{array}{c}-0.034 * * * \\
(-4.916)\end{array}$ & $\begin{array}{c}-0.020 \\
(-0.755)\end{array}$ & $\begin{array}{c}-0.054 * * * \\
(-5.075)\end{array}$ & $\begin{array}{c}-0.085 * * * \\
(-3.101)\end{array}$ & $\begin{array}{c}-0.006 \\
(-0.622)\end{array}$ & $\begin{array}{c}-0.022 * * * \\
(-2.909)\end{array}$ & $\begin{array}{c}-0.096 * * * \\
(-4.202)\end{array}$ \\
\hline $\mathbf{R M}_{t} \times \mathbf{J}_{-} \mathbf{B E A T}_{\mathbf{t}}$ & $\begin{array}{c}0.016 \\
(0.873)\end{array}$ & $\begin{array}{c}0.007 \\
(\mathbf{0 . 1 0 2})\end{array}$ & $\begin{array}{c}0.017 \\
(0.655)\end{array}$ & $\begin{array}{c}\mathbf{0 . 0 6 5} * * * \\
(3.531)\end{array}$ & $\begin{array}{c}-0.106 \\
(-1.622)\end{array}$ & $\begin{array}{l}0.038 * * \\
(2.004)\end{array}$ & $\begin{array}{c}0.088 \\
(1.214)\end{array}$ & $\begin{array}{c}0.008 \\
(0.288)\end{array}$ & $\begin{array}{c}0.053 * * * \\
(2.935)\end{array}$ & $\begin{array}{c}-0.029 \\
(-0.472)\end{array}$ \\
\hline $\mathrm{RM}_{\mathrm{t}} \times \mathrm{J} \_\mathrm{MISS}_{\mathrm{t}}$ & $\begin{array}{c}0.013 \\
(0.411)\end{array}$ & $\begin{array}{c}0.044 \\
(0.357)\end{array}$ & $\begin{array}{c}-0.018 \\
(-0.394)\end{array}$ & $\begin{array}{c}0.022 \\
(0.559)\end{array}$ & $\begin{array}{c}0.004 \\
(0.049)\end{array}$ & - & - & - & - & - \\
\hline $\mathrm{RM}_{\mathrm{t}} \times \mathrm{MISS}_{\mathrm{t}}$ & $\begin{array}{c}-0.056 * * \\
(-2.564)\end{array}$ & $\begin{array}{c}-0.111 * * \\
(-2.480)\end{array}$ & $\begin{array}{l}0.046^{* *} \\
(2.167)\end{array}$ & $\begin{array}{c}0.056 * * * \\
(2.719)\end{array}$ & $\begin{array}{c}-0.122 * * * \\
(-2.941)\end{array}$ & - & - & - & - & - \\
\hline Controls & Yes & Yes & Yes & Yes & Yes & Yes & Yes & Yes & Yes & Yes \\
\hline $\operatorname{Adj} R^{2}$ & $65.0 \%$ & $69.7 \%$ & $26.9 \%$ & $24.3 \%$ & $51.9 \%$ & $65.1 \%$ & $69.7 \%$ & $26.9 \%$ & $24.3 \%$ & $52.0 \%$ \\
\hline \# of obs. & 46,346 & 8,299 & 13,032 & 17,280 & 7,735 & 46,346 & 8,299 & 13,032 & 17,280 & 7,735 \\
\hline
\end{tabular}

Notes to Table 3

Equation (3): Future Performance $\left(\mathrm{CFO}_{\mathrm{t}+1}, \mathrm{CUM} \_\mathrm{ROA}\right)=\alpha+\beta_{1} \mathrm{~J}_{-} \mathrm{BEAT}_{\mathrm{t}}+\beta_{2} \mathrm{~J}_{-} \mathrm{MISS}_{\mathrm{t}}+\beta_{3} \mathrm{MISS}_{\mathrm{t}}+\beta_{4} \mathrm{RM}_{\mathrm{t}}+\beta_{5} \mathrm{RM}_{\mathrm{t}} \times \mathrm{J} \_\mathrm{BEAT}$ t $+\beta_{6} \mathrm{RM}_{\mathrm{t}} \times \mathrm{J}_{-} \mathrm{MISS}_{\mathrm{t}}+\beta_{7} \mathrm{RM}_{\mathrm{t}} \times \mathrm{MISS}_{\mathrm{t}}+\beta_{8} \mathrm{ADJ}_{-} \mathrm{ROA}_{\mathrm{t}}+\beta_{9} \log \left(\mathrm{ASSET}_{\mathrm{t}}\right)$

$+\beta_{10} \mathrm{MTB}_{\mathrm{t}}+\beta_{11}$ RETURN $_{\mathrm{t}}+\beta_{12}$ ZSCORE $_{\mathrm{t}}+$ Industry F.E. + Year F. E. + error.

1. Panel A provides the results of estimating equation (3) when the dependent variable is $\mathrm{CFO}_{\mathrm{t}+1}$.

2. Panel B provides the results of estimating equation (3) when the dependent variable is CUM_ROA.

3. The standard errors for computing t-statistics are corrected using firm and year clusters.

4. $*, * *$, and $* * *$ denote p-values at $10 \%, 5 \%$ and $1 \%$ for a two-tailed test.

5. Variable definitions are in Appendix A. 
Table 4: Avoiding losses, real-activity based earnings management and future performance: $M \& A$ and capital issue related incentive Panel A: Results of estimating equation (2)

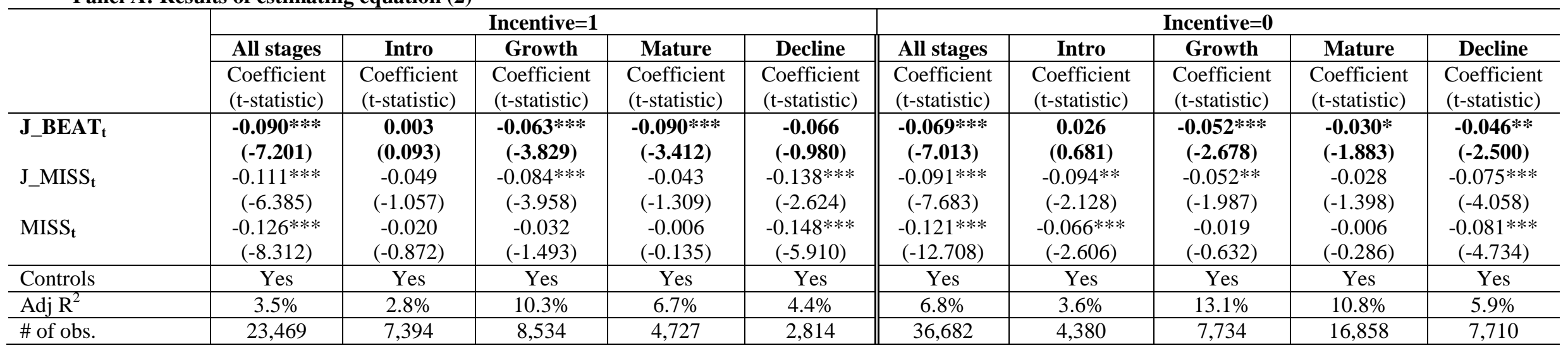

Panel B: Estimating equation (3)

\begin{tabular}{|c|c|c|c|c|c|c|c|c|c|c|}
\hline & \multicolumn{5}{|c|}{ Incentive $=1$} & \multicolumn{5}{|c|}{ Incentive $=0$} \\
\hline & All stages & Intro & Growth & Mature & Decline & All stages & Intro & Growth & Mature & Decline \\
\hline & $\begin{array}{l}\text { Coefficient } \\
\text { (t-statistic) }\end{array}$ & $\begin{array}{l}\text { Coefficient } \\
\text { (t-statistic) }\end{array}$ & $\begin{array}{l}\text { Coefficient } \\
\text { (t-statistic) }\end{array}$ & $\begin{array}{l}\text { Coefficient } \\
\text { (t-statistic) }\end{array}$ & $\begin{array}{l}\text { Coefficient } \\
\text { (t-statistic) }\end{array}$ & $\begin{array}{l}\text { Coefficient } \\
\text { (t-statistic) }\end{array}$ & $\begin{array}{l}\text { Coefficient } \\
\text { (t-statistic) }\end{array}$ & $\begin{array}{l}\text { Coefficient } \\
\text { (t-statistic) }\end{array}$ & $\begin{array}{l}\text { Coefficient } \\
\text { (t-statistic) }\end{array}$ & $\begin{array}{l}\text { Coefficient } \\
\text { (t-statistic) }\end{array}$ \\
\hline $\mathrm{J} \_B E A T_{t}$ & $\begin{array}{c}-0.042 * * * \\
(-5.109)\end{array}$ & $\begin{array}{c}-0.023 \\
(-0.981)\end{array}$ & $\begin{array}{c}-0.048 * * * \\
(-5.219)\end{array}$ & $\begin{array}{c}-0.046 * * * \\
(-3.541)\end{array}$ & $\begin{array}{c}-0.024 \\
(-0.695)\end{array}$ & $\begin{array}{c}-0.029 * * * \\
(-8.142)\end{array}$ & $\begin{array}{c}-0.007 \\
(-0.424)\end{array}$ & $\begin{array}{c}-0.026 * * * \\
(-3.359)\end{array}$ & $\begin{array}{c}-0.036 * * * \\
(-6.309)\end{array}$ & $\begin{array}{c}-0.006 \\
(-0.449)\end{array}$ \\
\hline $\mathrm{J}_{-} \mathrm{MISS}_{\mathrm{t}}$ & $\begin{array}{c}-0.032 * * * \\
(-3.908)\end{array}$ & $\begin{array}{c}-0.038 \\
(-1.394)\end{array}$ & $\begin{array}{c}-0.026 * * * \\
(-2.704)\end{array}$ & $\begin{array}{c}-0.045 * * * \\
(-3.351)\end{array}$ & $\begin{array}{c}-0.049 \\
(-1.182)\end{array}$ & $\begin{array}{c}-0.024 * * * \\
(-5.250)\end{array}$ & $\begin{array}{c}-0.036 \\
(-1.625)\end{array}$ & $\begin{array}{l}-0.016^{*} \\
(-1.651)\end{array}$ & $\begin{array}{c}-0.026 * * * \\
(-4.359)\end{array}$ & $\begin{array}{c}-0.019 \\
(-1.292)\end{array}$ \\
\hline $\mathrm{MISS}_{\mathrm{t}}$ & $\begin{array}{c}-0.039 * * * \\
(-4.775)\end{array}$ & $\begin{array}{c}-0.010 \\
(-0.661)\end{array}$ & $\begin{array}{c}-0.024 * * \\
(-2.049)\end{array}$ & $\begin{array}{c}-0.036 * * * \\
(-2.732)\end{array}$ & $\begin{array}{l}-0.030^{*} \\
(-1.866)\end{array}$ & $\begin{array}{c}-0.029 * * * \\
(-6.254)\end{array}$ & $\begin{array}{c}-0.010 \\
(-0.753)\end{array}$ & $\begin{array}{c}-0.014 \\
(-1.368)\end{array}$ & $\begin{array}{c}-0.018 * * * \\
(-3.251)\end{array}$ & $\begin{array}{l}-0.011 \\
(-1.207)\end{array}$ \\
\hline $\mathrm{RM}_{\mathrm{t}}$ & $\begin{array}{c}-0.012 * * * \\
(-3.813)\end{array}$ & $\begin{array}{c}-0.008 \\
(-0.673)\end{array}$ & $\begin{array}{c}-0.003 \\
(-0.790)\end{array}$ & $\begin{array}{c}-0.015 * * * \\
(-3.799)\end{array}$ & $\begin{array}{c}-0.027 \\
(-1.275)\end{array}$ & $\begin{array}{c}-0.008 * * * \\
(-3.872)\end{array}$ & $\begin{array}{c}-0.014 \\
(-1.093)\end{array}$ & $\begin{array}{c}-0.007 \\
(-1.589)\end{array}$ & $\begin{array}{c}-0.007 * * * \\
(-3.366)\end{array}$ & $\begin{array}{c}0.003 \\
(0.346)\end{array}$ \\
\hline $\mathbf{R M}_{\mathrm{t}} \times \mathbf{J} \_\mathbf{B E A T} \mathbf{T}_{\mathrm{t}}$ & $\begin{array}{r}0.026 * * \\
(2.041)\end{array}$ & $\begin{array}{c}0.019 \\
(0.618)\end{array}$ & $\begin{array}{l}0.021 * \\
(1.860)\end{array}$ & $\begin{array}{c}\mathbf{0 . 0 5 5 * * *} \\
(3.006)\end{array}$ & $\begin{array}{c}0.039 \\
(0.728)\end{array}$ & $\begin{array}{c}\mathbf{0 . 0 0 0} \\
(\mathbf{0 . 0 5 7})\end{array}$ & $\begin{array}{c}-0.038 \\
(-1.263)\end{array}$ & $\begin{array}{c}0.010 \\
(0.872)\end{array}$ & $\begin{array}{l}0.015 * \\
(1.895)\end{array}$ & $\begin{array}{c}-0.049 * * \\
(-2.048)\end{array}$ \\
\hline $\mathrm{RM}_{\mathrm{t}} \times \mathrm{J} \_\mathrm{MISS}_{\mathrm{t}}$ & $\begin{array}{c}0.027 \\
(1.275)\end{array}$ & $\begin{array}{c}0.046 \\
(0.699)\end{array}$ & $\begin{array}{c}0.004 \\
(0.209)\end{array}$ & $\begin{array}{l}0.056 * \\
(1.803)\end{array}$ & $\begin{array}{c}0.041 \\
(0.611)\end{array}$ & $\begin{array}{c}-0.006 \\
(-0.574)\end{array}$ & $\begin{array}{c}0.039 \\
(1.102)\end{array}$ & $\begin{array}{c}-0.020 \\
(-1.209)\end{array}$ & $\begin{array}{c}-0.002 \\
(-0.184)\end{array}$ & $\begin{array}{c}-0.009 \\
(-0.276)\end{array}$ \\
\hline $\mathrm{RM}_{\mathrm{t}} \times \mathrm{MISS}_{\mathrm{t}}$ & $\begin{array}{c}-0.029 * * * \\
(-2.980) \\
\end{array}$ & $\begin{array}{c}-0.040 * * \\
(-2.362) \\
\end{array}$ & $\begin{array}{c}0.002 \\
(0.196) \\
\end{array}$ & $\begin{array}{l}0.026 * \\
(1.935) \\
\end{array}$ & $\begin{array}{c}-0.024 \\
(-0.887) \\
\end{array}$ & $\begin{array}{l}-0.018 * \\
(-1.919) \\
\end{array}$ & $\begin{array}{l}-0.043^{*} \\
(-1.867) \\
\end{array}$ & $\begin{array}{l}0.019 * \\
(1.672) \\
\end{array}$ & $\begin{array}{c}0.016 * * \\
(2.263) \\
\end{array}$ & $\begin{array}{c}-0.033 * * \\
(-2.170) \\
\end{array}$ \\
\hline Controls & Yes & Yes & Yes & Yes & Yes & Yes & Yes & Yes & Yes & Yes \\
\hline $\operatorname{Adj} R^{2}$ & $72.1 \%$ & $71.5 \%$ & $29.1 \%$ & $32.7 \%$ & $63.2 \%$ & $58.9 \%$ & $67.3 \%$ & $30.4 \%$ & $29.7 \%$ & $46.7 \%$ \\
\hline \# of obs. & 23,469 & 7,394 & 8,534 & 4,727 & 2,814 & 36,682 & 4,380 & 7,734 & 16,858 & 7,710 \\
\hline
\end{tabular}




\section{Notes to Table 4}

Equation (2): AB RM $\mathrm{RM}_{t}=\alpha+\beta_{1} \mathrm{~J}_{\text {BEAT }}+\beta_{2} \mathrm{~J}_{-} \mathrm{MISS}_{\mathrm{t}}+\beta_{3} \mathrm{MISS}_{\mathrm{t}}+\beta_{4} \log \left(\mathrm{ASSET}_{\mathrm{t}}\right)+\beta_{5} \mathrm{MTB}_{\mathrm{t}}+\beta_{6} \mathrm{ROA}_{\mathrm{t}}+$ Industry F.E. + Year F. E. + error. Equation (3): ADJ_ROA ${ }_{t+1}=\alpha+\beta_{1} J_{-} B_{E A T}+\beta_{2} J_{-}$MISS $_{\mathrm{t}}+\beta_{3}$ MISS $_{\mathrm{t}}+\beta_{4} \mathrm{RM}_{\mathrm{t}}+\beta_{5} \mathrm{RM}_{\mathrm{t}} \times \mathrm{J}_{-} \mathrm{BEAT}_{\mathrm{t}}+\beta_{6} \mathrm{RM}_{\mathrm{t}} \times \mathrm{J} \_\mathrm{MISS}_{\mathrm{t}}+\beta_{7} \mathrm{RM}_{\mathrm{t}} \times \mathrm{MISS}_{\mathrm{t}}$

$+\beta_{8}$ ADJ_ROA ${ }_{t}+\beta_{9} \log \left(\operatorname{ASSET}_{\mathrm{t}}\right)+\beta_{10} \mathrm{MTB}_{\mathrm{t}}+\beta_{11}$ RETURN $_{\mathrm{t}}+\beta_{12}$ ZSCORE $_{\mathrm{t}}+$ Industry F.E. + Year F. E. + error.

1. The standard errors for computing t-statistics are corrected using firm and year clusters.

2 . $*, * *$, and $* * *$ denote p-values at $10 \%, 5 \%$ and $1 \%$ for a two-tailed test.

3. Variable definitions are in Appendix A. 
Table 5: Avoiding losses, components of real-activity based earnings management and future performance Panel A: Coefficient estimate on J_BEAT in equation (2)

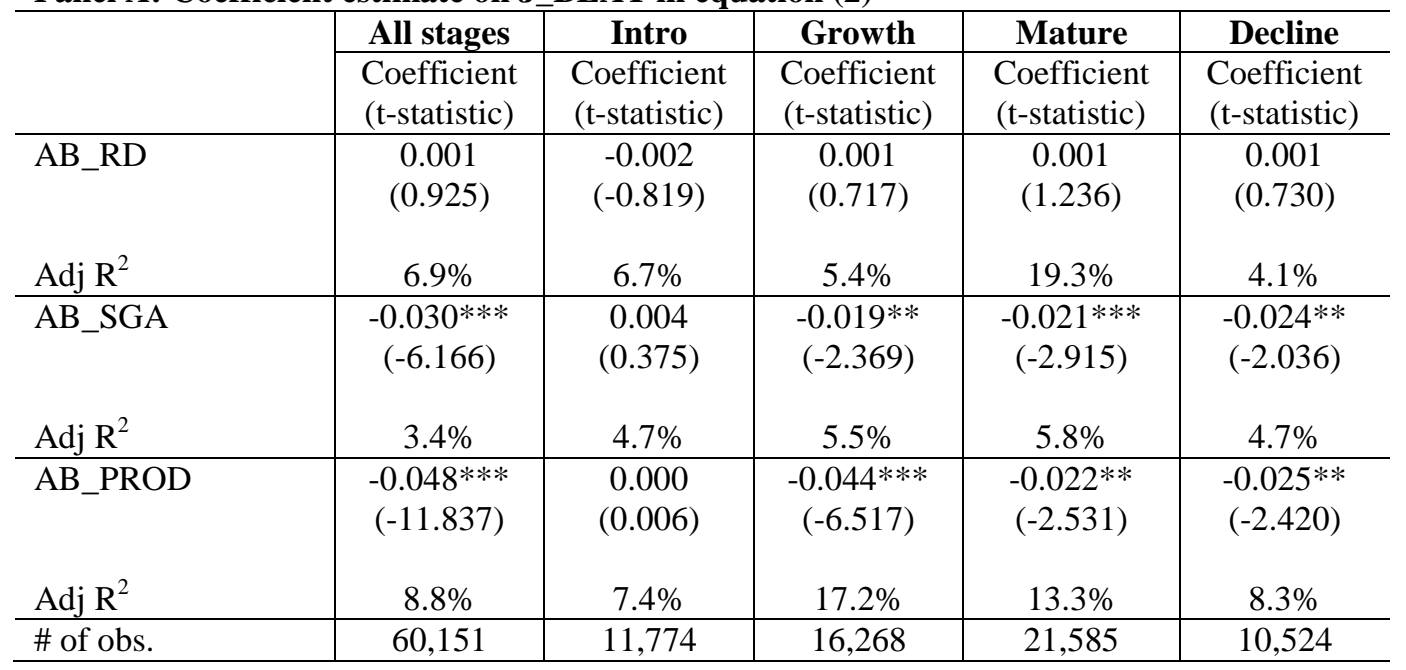

Panel B: Coefficient estimate on $\mathbf{R M} \times \mathbf{J} \_$BEAT in equation (3)

\begin{tabular}{l|c|c|c|c|c}
\hline & All stages & Intro & Growth & Mature & Decline \\
\cline { 2 - 6 } & $\begin{array}{c}\text { Coefficient } \\
\text { (t-statistic) }\end{array}$ & $\begin{array}{c}\text { Coefficient } \\
\text { (t-statistic) }\end{array}$ & $\begin{array}{c}\text { Coefficient } \\
\text { (t-statistic) }\end{array}$ & $\begin{array}{c}\text { Coefficient } \\
\text { (t-statistic) }\end{array}$ & $\begin{array}{c}\text { Coefficient } \\
\text { (t-statistic) }\end{array}$ \\
\hline AB_RD & $\begin{array}{c}0.003 \\
(0.324)\end{array}$ & $\begin{array}{c}0.065^{* *} \\
(2.035)\end{array}$ & $\begin{array}{c}-0.011 \\
(-0.714)\end{array}$ & $\begin{array}{c}-0.017 \\
(-1.058)\end{array}$ & $\begin{array}{c}0.022 \\
(1.193)\end{array}$ \\
& $67.6 \%$ & $70.5 \%$ & $29.3 \%$ & $30.2 \%$ & $55.7 \%$ \\
\hline Adj R ${ }^{2}$ & 0.004 & -0.016 & 0.011 & $0.018^{* *}$ & $-0.041^{*}$ \\
& $(0.603)$ & $(-0.610)$ & $(1.196)$ & $(2.024)$ & $(-1.834)$ \\
Adj_SGA ${ }^{2}$ & $67.5 \%$ & $70.4 \%$ & $29.3 \%$ & $30.2 \%$ & $55.8 \%$ \\
\hline AB_PROD & $0.012^{*}$ & 0.015 & $0.021 * *$ & $0.019 * *$ & -0.029 \\
& $(1.815)$ & $(0.732)$ & $(2.350)$ & $(2.227)$ & $(-1.439)$ \\
Adj R & & & & & \\
\# of obs. & $67.5 \%$ & $70.5 \%$ & $29.3 \%$ & $30.3 \%$ & $55.6 \%$ \\
\hline Notes to Table 5 & 60,151 & 11,774 & 16,268 & 21,585 & 10,524 \\
\hline
\end{tabular}

Notes to Table 5

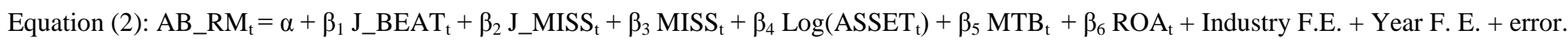


Equation (3): ADJ_ROA ${ }_{t+1}=\alpha+\beta_{1} J_{-} \mathrm{BEAT}_{\mathrm{t}}+\beta_{2} \mathrm{~J}_{-} \mathrm{MISS}_{\mathrm{t}}+\beta_{3} \mathrm{MISS}_{\mathrm{t}}+\beta_{4} \mathrm{RM}_{\mathrm{t}}+\beta_{5} \mathrm{RM}_{\mathrm{t}} \times \mathrm{J} \_\mathrm{BEAT}_{\mathrm{t}}+\beta_{6} \mathrm{RM}_{\mathrm{t}} \times \mathrm{JJ}_{-} \mathrm{MISS}_{\mathrm{t}}+\beta_{7} \mathrm{RM}_{\mathrm{t}} \times \mathrm{MISS}_{\mathrm{t}}+\beta_{8} \mathrm{ADJ}_{-} \mathrm{ROA}_{\mathrm{t}}$ $+\beta_{9} \log \left(\operatorname{ASSET}_{\mathrm{t}}\right)+\beta_{10}$ MTB $_{\mathrm{t}}+\beta_{11}$ RETURN $_{\mathrm{t}}+\beta_{12}$ ZSCORE $_{\mathrm{t}}+$ Industry F.E. + Year F. E. + error.

1. The standard errors for computing t-statistics are corrected using firm and year clusters.

2. $* * *$, and $* * *$ denote $\mathrm{p}$-values at $10 \%, 5 \%$ and $1 \%$ for a two-tailed test.

3. Variable definitions are in Appendix A.

4. In equation (2), AB_PROD is multiplied by minus 1 . 
Table 6: Results after deleting observations with small positive cash flow from operations

\begin{tabular}{|c|c|c|c|c|c|}
\hline & All stages & Intro & Growth & Mature & Decline \\
\hline & $\begin{array}{l}\text { Coefficient } \\
\text { (t-statistic) }\end{array}$ & $\begin{array}{l}\text { Coefficient } \\
\text { (t-statistic) }\end{array}$ & $\begin{array}{l}\text { Coefficient } \\
\text { (t-statistic) }\end{array}$ & $\begin{array}{l}\text { Coefficient } \\
\text { (t-statistic) }\end{array}$ & $\begin{array}{l}\text { Coefficient } \\
\text { (t-statistic) }\end{array}$ \\
\hline J_BEAT in equation (2) & $\begin{array}{c}-0.076 * * * \\
(-9.126)\end{array}$ & $\begin{array}{c}0.016 \\
(0.773)\end{array}$ & $\begin{array}{c}-0.056 * * * \\
(-4.132)\end{array}$ & $\begin{array}{c}-0.042 * * * \\
(-2.924)\end{array}$ & $\begin{array}{c}-0.059 * * * \\
(-3.167)\end{array}$ \\
\hline $\operatorname{Adj} R^{2}$ & $5.0 \%$ & $3.1 \%$ & $11.7 \%$ & $9.6 \%$ & $4.9 \%$ \\
\hline $\mathbf{R M} \times \mathbf{J} \_$BEAT in equation (3) & $\begin{array}{l}0.011^{*} \\
(1.798)\end{array}$ & $\begin{array}{c}-0.004 \\
(-0.203)\end{array}$ & $\begin{array}{l}0.020 * \\
(1.943)\end{array}$ & $\begin{array}{c}0.022 * * * \\
(2.702)\end{array}$ & $\begin{array}{c}-0.031 \\
(-1.519)\end{array}$ \\
\hline $\operatorname{Adj} R^{2}$ & $67.7 \%$ & $70.3 \%$ & $28.7 \%$ & $30.1 \%$ & $56.0 \%$ \\
\hline \# of obs. & 58,788 & 11,774 & 15,420 & 21,318 & 10,276 \\
\hline
\end{tabular}

\section{Notes to Table 6}

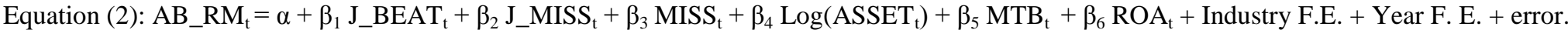

Equation (3): ADJ_ROA $\mathrm{t}_{\mathrm{t}+1}=\alpha+\beta_{1} \mathrm{~J}_{-} \mathrm{BEAT}+\beta_{2} \mathrm{~J} \_\mathrm{MISS}_{\mathrm{t}}+\beta_{3} \mathrm{MISS}_{\mathrm{t}}+\beta_{4} \mathrm{RM}_{\mathrm{t}}+\beta_{5} \mathrm{RM}_{\mathrm{t}} \times \mathrm{J}_{-} \mathrm{BEAT}_{\mathrm{t}}+\beta_{6} \mathrm{RM}_{\mathrm{t}} \times \mathrm{J} \_\mathrm{MISS} \mathrm{S}_{\mathrm{t}}+\beta_{7} \mathrm{RM}_{\mathrm{t}} \times \mathrm{MISS}_{\mathrm{t}}+\beta_{8} \mathrm{ADJ}_{-} \mathrm{ROA} \mathrm{A}_{\mathrm{t}}$ $+\beta_{9} \log \left(\mathrm{ASSET}_{\mathrm{t}}\right)+\beta_{10} \mathrm{MTB}_{\mathrm{t}}+\beta_{11} \mathrm{RETURN}_{\mathrm{t}}+\beta_{12} \mathrm{ZSCORE}_{\mathrm{t}}+$ Industry F.E. + Year F. E. + error.

1. The standard errors for computing t-statistics are corrected using firm and year clusters.

2. $*, * *$, and $* * *$ denote p-values at $10 \%, 5 \%$ and $1 \%$ for a two-tailed test.

3. Variable definitions are in Appendix A. 